
ROYAL ONTARIO MUSEUM 
Digitized by the Internet Archive in 2011 with funding from University of Toronto 

W. B. SCOTT AND M. G. SCOTT

LIBRARY

ROYAL ONTARIO MUSEUM UNIVERSITY OF TORONTO UNIVERSITY OFE TORONTO

\section{A checklist of}

Canadian Atlantic fishes

with keys for identification

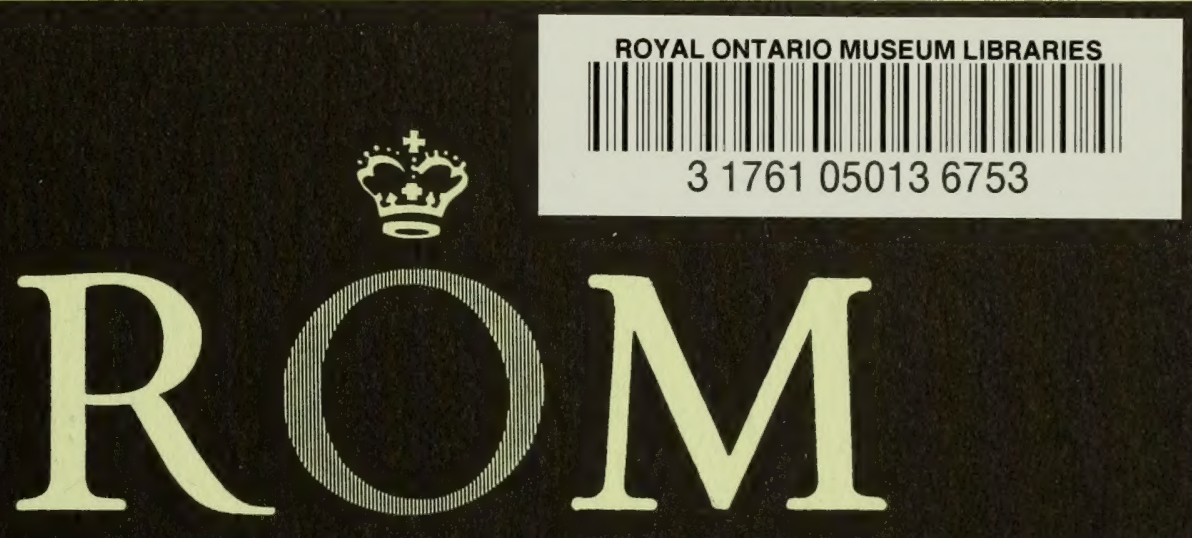



Contribution No. 66

LIFE SCIENCES

ROYAL ONTARIO MUSEUM

UNIVERSITY OF TORONTO

W. B. SCOTT AND

M. G. SCOTT

A checklist of

Canadian Atlantic fishes

with keys for identification 
w. B. Sсотт is Curator of Ichthyology and Herpetology, Royal Ontario Museum, University of Toronto.

PRICE : $\$ 1.25$

(C) The Governors of the University of Toronto, 1965

PRINTED AT THE UNIVERSITY OF TORONTO PRESS 


\section{INTRODUCTION}

The recent preparation of a text on the fishes of the Canadian Atlantic region for the Fisheries Research Board of Canada has brought into sharp focus the need for an inventory of the fishes occurring in this region. To this end a checklist of fishes inhabiting the region was prepared in mimeographed form in 1963 and circulated widely among the fisheries workers on the Atlantic coast in both the United States and Canada.

The main purpose of the present publication, listing 300 species in 115 families, is to make available in convenient form keys for the identification of the fishes of the region. For convenience in this list we have left unmarked those species represented by specimens existing in the collections maintained by the Royal Ontario Museum, the Biological Stations of the Fisheries Research Board of Canada (at St. John's, Nfld., and St. Andrews, N.B.), the National Museum of Canada, the Museum of Comparative Zoology or the United States National Museum. Those species marked with an asterisk are included on the basis of literature references only. While specimens from Canadian waters may exist in the aforementioned or other collections they are not known to us.

Knowledge of many of the groups is in a rather chaotic state. This is particularly so in the case of the iniomous fishes. In addition, adequate collections of Canadian Atlantic fishes are not readily available and thorough systematic collections of the fishes in the area have not been undertaken. In some cases, such as the lanternfishes, family Myctophidae, the listing is far from complete and our knowledge is very meagre indeed. Mrs. Isobel Radforth, research associate in our Department, is currently engaged in a study of this family of fishes and has kindly provided the key presented here. Mrs. Radforth's work is supported by financial assistance from the Fisheries Research Board of Canada.

The section of the Atlantic coast of North America here considered extends from Cape Chidley in northern Labrador to Georges Bank and is inhabited by 
arctic fishes whose southern distribution brings them into the area. At the same time, many of the fishes which occur (approximately 40\%) are essentially southern forms that move into the area either regularly or sporadically during the summer months. In the former category are such fishes as leatherfin and spiny lumpsuckers, seasnails, blennies and eelpouts, and the latter category includes such fishes as the bluefin tuna, swordfish, members of the family Carangidae, marlins and filefishes. There are also forms included whose normal range is the eastern Atlantic but which have been taken in recent years in this area, such as Molva molva, Molva byrkelange and Lagocephalus lagocephalus. From the list it will be obvious that the fauna is relatively rich and certainly more species inhabit the area than was previously thought.

A set of keys for the fishes of the region has not been available since the publication in 1935 of "The Marine Fishes of Nova Scotia" by V. D. Vladykov and R. A. McKenzie, long since out of print. It has been traditional for workers in the Canadian area to use the well known work by H. B. Bigelow and W. C. Schroeder, published in 1935, entitled "Fishes of the Gulf of Maine", but the keys contained in the latter publication do not cover completely the fauna occurring in the Canadian area.

It is not expected that the keys on the following pages will be without error. As all students will testify, faunal keys only become smooth working and efficient after much use and constant revision. It is our sincere hope that errors or omissions will be reported to the authors so that subsequent revisions may be improved.

The keys have been constructed so that anyone not familiar with fishes can commence by using the Key to Major Categories and determine whether the unknown animal is a lamprey, shark, ray, chimaera or bony fish. If a bony fish, the Key to the Orders and Families of Bony Fishes ( $p .28)$ will enable the reader to determine if the fish in hand is a herring, a salmonid, a stickleback, etc. Final specific identification can be made by referring to the appropriate family key. Species have been included in the keys which do not appear in the checklist since these species may be found to occur in the region. 
If a fish is encountered in Canadian Atlantic waters which is not readily identifiable by the use of these keys we should be pleased to have it sent to the Royal Ontario Museum, 100 Queens Park, Toronto 5, Ontario, or to the Biological Station, Fisheries Research Board of Canada, St. Andrews, New Brunswick, or to the Biological Station, Fisheries Research Board of Canada, St. John's, Newfoundland.

\section{ACKNOWLEDGMENTS}

For comments and criticisms of the 1963 checklist we are especially grateful to H. B. Bigelow, D. M. Cohen, B. B. Collette, D. de Sylva, A. R. Emery, R. H. Gibbs, Marion Grey, R. Haedrich, D. E. McAllister, G. W. Mead, R. R. Miller, L. W. Scattergood and W. C. Schroeder. Thanks are due to Dr. W. E. Swinton and Dr. E. J. Crossman for critical reading, and to Mrs. Radforth for the myctophid key. We are grateful to $\mathrm{Mr}$. Peter Buerschaper for testing many of the keys in our laboratory. The stylized myctophid was drawn by Mr. Bon Harriott, the salmonid and all lettering by Mr. P. Geraghty. 


\section{CHECKLIST}

\section{Class MARSIPOBRANCHII}

Order HYPEROTRETA (Myxiniformes) - hagfishes

f. Myxinidae - hagfishes

Myxine glutinosa Linnaeus 1758 - northern hagfish

Order HYPEROARTIA (Petromyzontiformes) - lampreys

f. Petromyzontidae - lampreys

Petromyzon marinus Linnaeus 1758 - sea lamprey

\section{Class SELACHII}

Order PLEUROTREMATA (Squaliformes) - sharks

f. Carchariidae - sand sharks

Carcharias taurus Rafinesque 1810 - sand shark*

f. Alopiidae - thresher sharks

Alopias vulpinus (Bonnaterre) 1788 - thresher shark*

f. Cetorhinidae - basking sharks

Cetorhinus maximus (Gunnerus) 1765 - basking shark

f. Lamnidae - mackerel sharks

Carcharodon carcharias (Linnaeus) 1758 - white shark Lamna nasus (Bonnaterre) 1788 - porbeagle Isurus oxyrinchus Rafinesque 1810 - mako

f. Scyliorhinidae - cat sharks Apristurus profundorum (Goode and Bean) 1896 - deepsea cat shark*

$$
\text { f. Carcharhinidae - requiem sharks }
$$

(maneating sharks)

Carcharhinus longimanus (Poey) 1861 - whitetip shark Carcharhinus obscurus (LeSueur) 1818 - dusky shark Mustelus canis (Mitchil1) 1815 - smooth dogfish* 
Prionace glauca (Linnaeus) 1758 - blue shark

Rhizoprionodon terraenovae (Richardson) 1836 - Atlantic sharpnose shark

f. Sphyrnidae - hammerhead sharks

Sphyrna zygaena (Linnaeus) 1758 - smooth hammerhead*

f. Dalatiidae - sleeper or gurry sharks

Somniosus microcephalus (Bloch and Schneider) 1801 Green land shark

f. Squalidae - dogfish sharks

Centroscyllium fabricii (Reinhardt) 1825 - black dogfish Centroscymnus coelolepis Bocage and Brito Capello 1864 Portuguese shark

Etmopterus princeps Collett 1904 - rough sagre*

Squalus acanthias Linnaeus 1758 - spiny dogfish

Order HYPOTREMATA (Rajiformes) - rays

f. Rajidae - skates

Raja erinacea Mitchill 1825 - little skate

Raja bathyphila Holte and Byrne 1908 - abyssal skate*

Raja fyllae Lütken 1887 - round skate*

Raja jenseni Bigelow and Schroeder 1950 - Jensen's skate

Raja laevis Mitchill 1817 - barndoor skate

Raja 1intea Fries 1838 - white skate

Raja mollis Bigelow and Schroeder 1950 - soft skate

Raja ocellata Mitchill 1815 - winter skate

Raja radiata Donovan 1807 - thorny skate

Raja senta Garman 1885 - smooth skate

Raja spinicauda Jensen 1914 - spinytail skate

f. Dasyatidae (or Trygonidae) - stingrays

Dasyatis centroura (Mitchill) 1815 - roughtail stingray*

f. Mobulidae - mantas or devilfishes

Manta birostris (Walbaum) 1792 - Atlantic manta

f. Torpedinidae - electric rays, torpedos

Torpedo nobiliana Bonaparte 1835 - Atlantic torpedo* 


\section{Order CHIMAERIFORMES - chimaeras}

f. Chimaeridae - chimaeras, ratfishes or ghost sharks

Hydrolagus affinis (Cape110) 1868 - deepwater chimaera Harriotta raleighana Goode and Bean 1895 - longnose chimaera

Rhinochimaera atlantica Holte and Byrne 1909 - knifenose chimaera

\section{Class PISCES (Osteichthys)}

Order CHONDROSTEI (Acipenseriformes) - chondrosteans

$$
\text { f. Acipenseridae - sturgeons }
$$

Acipenser brevirostrum LeSueur 1818 - shortnose sturgeon Acipenser oxyrhynchus Mitchill 1815 - American Atlantic sturgeon

$$
\text { Order GINGLYMODI (Semionotiformes) - gars }
$$

$$
\text { f. Lepisosteidae - gars }
$$

Lepisosteus osseus (Linnaeus) 1758 - longnose gar

$$
\text { Order ISOSPONDYLI (Clupeiformes) - isospondyls }
$$

Suborder Clupeoidea

$$
\text { f. Elopidae - tarpons }
$$

Megalops atlanticus Valenciennes 1847 - tarpon*

$$
\text { f. Albulidae - bonefishes }
$$

Albula vulpes (Linnaeus) 1758 - bonefish*

\section{f. Clupeidae - true herrings}

Alosa aestivalis (Mitchill) 1815 - blueback herring* Alosa pseudoharengus (Wilson) 1811 - gaspereau, alewife Alosa sapidissima (Wilson) 1811 - American shad Brevoortia tyrannus (Latrobe) 1802 - Atlantic menhaden Clupea harengus harengus Linnaeus 1758 - Atlantic herring Etrumeus sadina (Mitchil1) 1815 - Atlantic round herring 
f. Engraulidae - anchovies

Anchoa hepsetus (Linnaeus) 1758 - striped anchovy*

f. Alepocephalidae - smoothheads

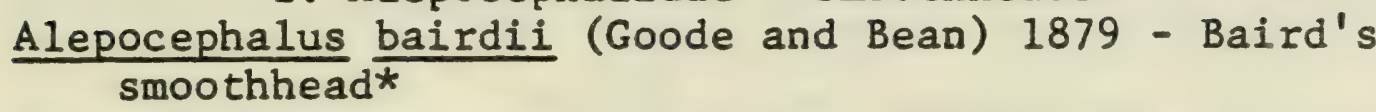

Xenodermichthys socialis Vaillant 1888 - Atlantic gymnast*

Suborder Salmonoidea

f. Salmonidae - salmon, trouts, chars and whitefishes

Coregonus clupeaformis (Mitchil1) 1818 - lake whitefish Coregonus sp. - Atlantic whitefish

Oncorhynchus gorbuscha (Walbaum) 1792 - pink salmon Salmo gairdneri Richardson 1836 - rainbow trout Salmo salar Linnaeus 1758 - Atlantic salmon Salmo trutta Linnaeus 1758 - brown trout Salvelinus alpinus (Linnaeus) 1758 - arctic char Salvelinus fontinalis (Mitchil1) 1815 - brook trout

\section{f. Osmeridae - smelts}

Mallotus villosus (Müller) 1777 - capelin osmerus mordax (Mitchil1) 1815 - American smelt

\section{f. Argentinidae - argentines}

Argentina silus Ascanius 1763 - Atlantic argentine Argentina striata Goode and Bean 1896 - striated argentine*

Nansenia groenlandica (Reinhardt) 1839 - large-eyed argentine

\section{f. Bathylagidae - blacksmelts}

Bathylagus euryops Goode and Bean 1895 - goitre blacksmelt

\section{Suborder Stomiatoidea}

\section{f. Gonostomidae - anglemouths}

Cyclothone braueri Jesperson and Tåning 1926 - Brauer's anglemouth*

Cyclothone microdon (Günther) 1878 - veiled anglemouth Gonostoma elongatum Günther 1878 - longtooth anglemouth* 
Maurolicus muelleri (Gmelin) 1788 - Müller's pearlsides

f. Sternoptychidae - silver hatchetfishes Argyropelecus aculeatus Cuvier and Valenciennes 1849 Atlantic silver hatchetfish

Polyipnus asteroides Schultz 1938 -

Sternoptyx diaphana Hermann 1781 - transparent hatchetfish

f. Chauliodontidae - viperfishes

Chauliodus sloani Bloch and Schneider 1801 - viperfish

f. Stomiatidae - scaled dragonfishes

Stomias boa ferox Reinhardt 1842 - boa dragonfish

f. Astronesthidae - bighead dragonfishes

Borostomias antarcticus (Lönnberg) 1905 - straightline dragonfish*

f. Melanostomiatidae - smooth dragonfishes Grammatostomias dentatus Goode and Bean 1895 - torpedo dragonfish*

Melanostomias spilorhynchus Regan and Trewavas 1930 bluenose dragonfish*

Trigonolampa miriceps Regan and Trewavas 1930 - threelight dragonfish

f. Idiacanthidae - sawtailfishes

Idiacanthus fasciola Peters 1876 - ribbon sawtailfish

f. Malacosteidae - loosejaws

Malacosteus niger Ayres 1848 - loosejaw

Order INIOMI (Myctophiformes, Scopeliformes) - iniomes

f. Myctophidae - lanternfishes

Aethoprora metopoclampa (Cocco) 1829 - headlight fish

Benthosema glaciale (Reinhardt) 1837 - glacier

lanternfish

Ceratoscopelus madeirensis (Lowe) 1839 - horned

lanternfish

Gonichthys coccoi (Cocco) 1829 - Cocco's lanternfish* Hygophum benoiti (Cocco) 1838 - Benoit's lanternfish* Lampadena speculigera Goode and Bean 1879 - mirror lanternfish* 
Lampanyctus crocodilus (Risso) 1810 - jewel lanternfish* Myctophum affine (Lütken) 1892 - metallic lanternfish* Myctophum punctatum Rafinesque 1810 - spotted lanternfish Notoscopelus krфyeri (Malm) 1863 - Krфyer's lanternfish Symbolophorus veranyi (Moreau) 1888 - largescale lanternfish

In addition to the genera noted above, the key to the myctophid fishes includes the following 11 genera: Centrobranchus, Diaphus, Diogenichthys, Hierops, Lepidophanes, Lobianchia, Loweina, Neoscopelus, Notolychnus, Scopelopsis, Taaningichthys. A more detailed listing seems unwarranted in view of the very limited information available on this group of fishes in the Canadian Atlantic region.

f. Bathypteroidae - feelerfishes

Bathypterois dubius Vaillant 1888 - notch feelerfish

f. Paralepididae (Sudidae) barracudinas

Paralepis brevis brevis Zugmayer 1911 - short barracudina

Paralepis rissoi krфyeri Bonaparte 1840 - white barracudina

f. Alepisauridae - lancetfishes

Alepisaurus brevirostris Gibbs 1960 - shortnose lancetfish

Alepisaurus ferox Lowe 1833 - longnose lancetfish

f. Anotopteridae - daggertoothfishes

Anotopterus pharao Zugmayer 1911 - daggertooth

Order LYOMERI (Saccopharyngiformes) - gulpers

f. Eurypharyngidae - gulpers

Eurypharynx pelecanoides Vaillant 1882 - pelican gulper*

Order APODES (Anguilliformes) - true eels

f. Anguilidae - common eels

Anguilla rostrata (LeSueur) 1817 - American eel

f. Simenchelyidae - snubnose eels

Simenchelys parasiticus Gill 1879 - snubnose eel 


\section{f. Muraenidae - morays}

Gymnothorax funebris Ranzani 1840 - green moray

f. Nemichthyidae - snipe eels

Nemichthys scolopaceus Richardson 1848 - Atlantic snipe eel

Serrivomer beani Gill and Ryder 1883 - stout sawpalate*

f. Nessorhamphidae - duckbill eels

Nessorhamphus ingolfianus (Schmidt) 1912 - duckbill oceanic eel

f. Congridae - congers

Conger oceanicus (Mitchil1) 1818 - American conger

f. Ophichthidae - snake eels

Omochelys cruentifer (Goode and Bean) 1896 - snake eel

f. Synaphobranchidae - cutthroat eels

Synaphobranchus kaupi Johnston 1862 - Gray's cutthroat ee1

Order HETEROMI (Notacanthiformes) - tapirfishes

f. Notacanthidae - spiny tapirfishes

Macdonaldia rostrata (Collett) 1889 - shortspine tapirfish

Notacanthus nasus Bloch 1795 - largescale tapirfish

f. Lipogenyidae - backfin tapirfishes

Lipogenys gillii Goode and Bean 1895 - backfin tapirfish

Order SYNENTOGNATHI (Beloniformes) - sauries,

f. Scomberesocidae - sauries flyingfishes

Scomberesox saurus (Walbaum) 1792 - Atlantic saury

f. Hemiramphidae - halfbeaks

Hyporhamphus sp. - common halfbeak

f. Exocoetidae - flyingfishes

Cypselurus furcatus (Mitchill) 1815 - spotfin flyingfish Cypselurus heterurus (Rafinesque) 1810 - Atlantic flying fish * 
Order MICROCYPRINI (Cyprinodontiformes) - killifishes

f. Cyprinodontidae - killifishes, topminnows Fundulus diaphanus (LeSueur) 1817 - banded killifish Fundulus heteroclitus (Linnaeus) 1766 - mummichog

$$
\begin{gathered}
\text { Order SOLENICHTHYS - coronetfishes, seahorses, } \\
\text { pipefishes } \\
\text { f. Fistularilae - coronetfishes }
\end{gathered}
$$

Fistularia tabacaria Linnaeus 1758 - coronetfish

f. Syngnathidae - seahorses, pipefishes Hippocampus erectus Perry 1810 - spotted seahorse Syngnathus fuscus Storer 1839 - northern pipefish

Order THORACOSTEI (Gasterosteiformes) - sticklebacks

f. Gasterosteidae - sticklebacks

Apeltes quadracus (Mitchi11) 1815 - fourspine stickleback Gasterosteus aculeatus Linnaeus 1758 - threespine stickleback

Gasterosteus wheatlandi Putnam 1867 - blackspotted stickleback

Pungitius pungitius (Linnaeus) 1758 - ninespine stickleback

Order ANACANTHINI (Gadiformes) - gadoids

f. Moridae - moras

Antimora rostrata Günther 1878 - blue antimora

Halargyreus brevipes Vaillant 1888 - dainty mora

$$
\text { f. Gadidae - cods }
$$

Boreogadus saida (Lepechin) 1774 - arctic cod

Brosme brosme (Müller) 1776 - cusk

Enchelyopus cimbrius (Linnaeus) 1766 - fourbeard rockling Gadus morhua Linnaeus 1758 - Atlantic cod

Gadus ogac Richardson 1836 - Greenland cod

Gaidropsarus argentatus (Reinhardt) 1838 - silver rockling

Gaidropsarus ensis (Reinhardt) 1838 - threebeard rockling Melanogrammus aeglefinus (Linnaeus) 1758 - haddock Merluccius albidus (Mitchi11) 1818 - offshore hake 
Merluccius bilinearis (Mitchill) 1814 - silver hake Microgadus tomcod (Walbaum) 1792 - Atlantic tomcod Micromesistius poutassou (Risso) 1826 - blue whiting Molva byrkelange (Walbaum) 1792 - blue 1ing* Molva molva (Linnaeus) 1758 - European ling* Pollachius virens (Linnaeus) 1758 - pollock Urophycis chesteri (Goode and Bean) 1878 - longfin hake Urophycis chuss (Walbaum) 1792 - squirrel hake Urophycis regius (Walbaum) 1792 - spotted hake Urophycis tenuis (Mitchil1) 1815 - white hake

\section{f. Macrouridae - grenadiers, rat-tails}

Coelorhynchus carninatus (Goode) 1880 - longnose grenadier*

Coryphaenoides rupestris Gunnerus 1765 - rock grenadier Macrourus berglax Lacépède 1802 - roughhead grenadier Malacocephalus occidentalis Goode and Bean 1885 American straptail grenadier*

Nezumia bairdi (Goode and Bean) 1877 - marlin-spike Trachyrhynchus murrayi Günther 1887 - roughnose grenadier

Order ALLOTRIOGNATHI (Lampridiformes) - opahs

f. Lamprididae - opahs

Lampris regius (Bonnaterre) 1788 - opah

Order BERYCOMORPHI (Beryciformes) - berycoid fishes

f. Polymixildae - beardfishes

Polymixia nobilis Lowe 1838 - stout beardfish

f. Berycidae - alfonsinos

Beryx decadactylus Cuvier 1829 - alfonsin a Casta Larga* Beryx splendens Lowe 1833 - alfonsin a Casta*

f. Diretmidae - spinyfins

Diretmus argenteus Johnson 1863 - spinyfin

f. Anoplogasteridae - ogrefishes

Anoplogaster cornuta Valenciennes 1888 - ogrefish

f. Melamphaidae - bluebacks

Scopelogadus beanii (Günther) 1887 - Bean's blueback 
Order ZEOMORPHI (Zeiformes) - dories

f. Zeidae - dories

Zenopsis ocellata (Storer) 1858 - American John Dory

f. Gramicolepidae - grammicolepids

Xenolepidichthys americanus Nichols and Firth 1949 gramicolepid $\star$

Order PERCOMORPHI (Perciformes) - spinyrayed fishes

f. Serranidae - basses

Epinephelus morio (Valenciennes) 1828 - red grouper* Polyprion americanus (Bloch and Schneider) 1801 Atlantic wreckfish*

Roccus americanus (Gmelin) 1789 - white perch

Roccus saxatilis (Walbaum) 1792 - striped bass

f. Apogonidae - cardinalfishes

Rhectogramma sherborni Norman 1930 - Sherborn's cardinalfish

f. Branchiostegidae - tilefishes

Lopholatilus chamaeleonticeps Goode and Bean 1879 tilefish

\section{f. Pomatomidae - bluefishes}

Pomatomus saltatrix (Linnaeus) 1758 - bluefish

f. Carangidae - jacks and pompanos

Caranx crysos (Mitchili) 1815 - blue runner

Caranx hippos (Linnaeus) 1766 - crevalle jack*

Decapterus macarellus (Cuvier) 1833 - mackerel scad

Naucrates ductor (Linnaeus) 1758 - pilotfish

Selene vomer (Linnaeus) 1758 - Atlantic lookdown*

Seriola zonata (Mitchili) 1815 - banded rudderfish

Selar crumenophthalmus (Bloch) 1793 - bigeye scad

Vomer setapinnis (Mitchill) 1815 - Atlantic moonfish*

f. Coryphaenidae - dolphins

Coryphaena hippurus Linnaeus 1758 - dolphin

f. Bramidae - pomfrets

Brama rayi (Bloch) 1791 - smallscale pomfret 
Taractes longipinnis (Lowe) 1843 - bigscale pomfret*

f. Sciaenidae - drums or croakers

Cynoscion regalis (Bloch and Schneider) 1801 - weakfish

Pogonias cromis (Linnaeus) 1766 - black drum

f. Mullidae - surmullets

Mullus auratus Jordan and Gilbert 1882 - red goatfish*

f. Sparidae - porgies

Archosargus probatocephalus (Walbaum) 1792 - sheepshead* Stenotomus chrysops (Linnaeus) 1766 - scup

f. Chaetodontidae - butterflyfishes

Chaetodon ocellatus Bloch 1787 - spotfin butterflyfish

f. Labridae - wrasses

Tautoga onitis (Linnaeus) 1758 - tautog

Tautogolabrus adspersus (Walbaum) 1792 - cunner

f. Ammodytidae - sand lances

Ammodytes americanus DeKay 1842 - American sand lance

Ammodytes dubius Reinhardt 1838 - northern sand lance

f. Chiasmodontidae - black swallowers Chiasmodon niger Johnson 1863 - black swallower

f. Gempylidae - snake mackerels

Lepidocybium flavobrunneum (Smith) 1849 - escolar Ruvettus pretiosus Cocco 1829 - oilfish

f. Trichiuridae - cutlassfishes or hairtails Aphanopus carbo Lowe 1839 - black scabbardfish Benthodesmus simonyi (Steindachner) 1891 - frostfish

f. Scombridae - mackerels and tunas Auxis thazard (Lacépède) 1802 - frigate mackerel Euthynnus pelamis (Linnaeus) 1758 - skipjack Sarda sarda (Bloch) 1793 - Atlantic bonito* Scomber colias Gmelin 1789 - chub mackerel Scomber Scombrus Linnaeus 1758 - Atlantic mackerel Thunnus alalunga (Bonnaterre) 1788 - albacore Thunnus albacares (Bonnaterre) 1788 - yellowfin tuna* Thunnus obesus (Lowe) 1839 - bigeye tuna Thunnus thynnus (Linnaeus) 1758 - bluefin tuna 
f. Istiophoridae - spearfishes and sailfishes or marlins

Makaira albida (Poey) 1860 - white marlin

Makaira nigricans Lacépède 1803 - blue marlin

f. Xiphildae - swordfishes

Xiphias gladius Linnaeus 1758 - swordfish

f. Anarhichadidae - wolffishes

Anarhichas denticulatus Krфyer 1844 - northern wolffish

Anarhichas lupus Linnaeus 1758 - Atlantic wolffish

Anarhichas minor Olafsen 1774 - spotted wolffish

f. Pholidae - gunnels

Pholis fasciata (Bloch and Schneider) 1801 - banded gunne1

Pholis gunnellus (Linnaeus) 1758 - rock gunnel

f. Stichaeidae - pricklebacks

Chirolophus ascani (Walbaum) 1792 - Yarrell's blenny* Cryptacanthodes maculatus Storer 1839 - wrymouth Eumesogrammus praecisus (Krbyer) 1837 - fourline snakeblenny

Lumpenus maculatus (Fries) 1837 - daubed shanny

Lumpenus fabricii (Valenciennes) 1836 - slender eelblenny

Lumpenus Iumpretaefornis (Walbaum) 1792 - snake blenny

Lumpenus medius (Reinhardt) 1838 - stout eelblenny

Stichaeus punctatus (Fabricius) 1780 - arctic shanny

Ulvaria subbifurcata (Storer) 1839 - radiated shanny

\section{f. Zoarcidae - eelpouts}

Gymnelis viridis (Fabricius) 1780 - fish doctor

Lycenchelys paxillus (Goode and Bean) 1879 - common wolf eel

Lycenchelys sarsi (Collett) 1871 - Sars' wolf eel

Lycenchelys verrilii (Goode and Bean) 1877 - wolf eelpout

Lycodes atlanticus Jensen 1902 - Atlantic eelpout

Lycodes esmarki Collett 1875 - Esmark's eelpout

Lycodes lavalaei Vladykov and Tremblay 1936 - Laval's eelpout

Lycodes pallidus Collett 1879 - pale eelpout

Lycodes reticulatus Reinhardt 1838 - arctic eelpout

Lycodes turneri Bean 1878 - polar eelpout

Lycodes vahlii Reinhardt 1838 - Vahl's eelpout

Macrozoarces americanus (Bloch and Schneider) 1801 ocean pout 
Melanostigma atlanticum Koefoed 1952 - Atlantic soft pout

f. Stromateidae - butterfishes

Nomeus gronowi (Gmelin) 1788 - man-o'-war fish

Palinurichthys perciformis (Mitchili) 1818 - American barrelfish

Poronotus triacanthus (Peck) 1800 - butterfish

Suborder Mugiloidea

f. Mugilidae - mullets

Mugil cephalus Linnaeus 1758 - striped mullet*

f. Atherinidae - silversides

Menidia menidia (Linnaeus) 1766 - Atlantic silverside

Order SCLEROPAREI (Cottiformes) - sculpins

f. Scorpaenidae - rockfishes

Helicolenus dactylopterus (De la Roche) 1809 - blackbelly rosefish

Sebastes marinus (Linnaeus) 1758 - redfish

\section{f. Triglidae - searobins}

Prionotus carolinus (Linnaeus) 1771 - northern searobin

Prionotus evolans (Linnaeus) 1766 - striped searobin

f. Cottidae - sculpins

Artediellus uncinatus (Reinhardt) 1833 - arctic hookear sculpin

Cottunculus microps Collett 1875 - polar sculpin

Cottunculus thompsoni (Günther) 1882 - pallid sculpin

Gymnocanthus tricuspis (Reinhardt) 1832 - arctic staghorn sculpin

Hemitripterus americanus (Gmelin) 1789 - sea raven

Icelus bicornis (Reinhardt) 1841 - twohorn sculpin

Icelus spatula Gilbert and Burke 1912 - spatulate sculpin

Myoxocephalus aeneus (Mitchill) 1815 - grubby

Myoxocephalus octodecemspinosus (Mitchill) 1815 longhorn sculpin

Myoxocephalus quadricornis (Linnaeus) 1758 - fourhorn sculpin

Myoxocephalus scorpius (Linnaeus) 1758 - shorthorn sculpin 
Myoxocephalus scorpioides (Fabricius) 1780 - arctic sculpin

Triglops murrayi Günther 1888 - mailed sculpin

Triglops nybelini Jensen 1944 - Nybelin's sculpin

Triglops pingeli Reinhardt 1832 - ribbed sculpin

f. Agonidae - poachers and alligatorfishes

Agonus decagonus Bloch and Schneider 1801 - Atlantic sea poacher

Aspidophoroides monopterygius (B1och) 1786 - alligatorfish

Aspidophoroides olriki Lütken 1876 - arctic alligatorfish

f. Cyclopteridae - lumpfishes and seasnails

Cyclopterus lumpus Linnaeus 1758 - lumpfish

Eumicrotremus derjugini Popov 1926 - leatherfin lumpsucker

Eumicrotremus spinosus (Müller) 1777 - Atlantic spiny lumpsucker

Careproctus Iongipinnis Burke 1912 - Iongfin seasnail

Careproctus reinhardi (Krфyer) 1862 - sea tadpole*

Liparis atlanticus (Jordan and Evermann) 1898 - Atlantic seasnail

Liparis cyclostigma Gilbert 1895 - polka-dot seasnail

Liparis koefoedi Parr 1932 - gelatinous seasnail

Liparis liparis (Linnaeus) 1766 - striped seasnail

Liparis tunicatus Reinhardt 1836 - Greenland seasnail

Paraliparis copei Goode and Bean 1896 - blacksnout seasnail

f. Dactylopteridae - flying gurnards

Dactylopterus volitans (Linnaeus) 1758 - flying gurnard*

Order HETEROSOMATA (Pleuronectiformes) - flatfishes

f. Bothidae - lefteye flounders

Paralichthys dentatus (Linnaeus) 1766 - summer flounder*

Paralichthys oblongus (Mitchil1) 1815 - fourspot flounder Scophthalmus aquosus (Mitchil1) 1815 - windowpane

f. Pleuronectidae - flounders

Glyptocephalus cynoglossus (Linnaeus) 1758 - witch flounder

Hippoglossoides platessoides (Fabricius) 1780 - American plaice

Hippoglossus hippoglossus (Linnaeus) 1758 - Atlantic halibut 
Limanda ferruginea (Storer) 1839 - yellowtail flounder Liopsetta putnami (Gi11) 1864 - smooth flounder Pseudopleuronectes americanus (Walbaum) 1792 - winter flounder

Reinhardtius hippoglossoides (Walbaum) 1792 - Greenland halibut

\section{Order DISCOCEPHALI (Echeneiformes) - remoras}

f. Echeneidae - sharksuckers

Echeneis naucrates Linnaeus 1758 - sharksucker* Remora brachyptera (Lowe) 1839 - spearfish remora Remora remora (Linnaeus) 1758 - remora

Order PLECTOGNATHI (Tetraodontiformes) - triggerfishes, trunkfishes, puffers, headfishes

f. Monacanthidae - filefishes

Alutera schoepfi (Walbaum) 1792 - orange filefish Alutera scripta (Osbeck) 1757 - scrawled filefish* Monacanthus ciliatus (Mitchil1) 1818 - fringed filefish* Monacanthus hispidus (Linnaeus) 1766 - planehead filefish

\section{f. Balistidae - triggerfishes}

Balistes capriscus Gmelin 1789 - gray triggerfish Balistes vetula Linnaeus 1758 - queen triggerfish*

f. Ostraciontidae - boxfishes or trunkfishes Lactophrys trigonus (Linnaeus) 1758 - trunkfish*

f. Tetraodontidae - globefishes or puffers Lagocephalus lagocephalus Linnaeus 1758 - oceanic puffer Sphoeroides maculatus (BIoch and Schneider) 1801 northern puffer

f. Diodontidae - porcupinefishes

Chilomycterus schoepfi (Walbaum) 1792 - striped burrfish* f. Molidae - ocean sunfishes or headfishes Mola mola (Linnaeus) 1758 - ocean sunfish* 
Order PEDICULATI (Lophiformes) - anglerfishes

f. Lophiidae - goosefishes

Lophius americanus Valenciennes 1837 - monkfish

f. Antennariidae - frogfishes

Histrio histrio Linnaeus 1758 - sargassumfish

f. Ceratiidae - anglerfishes

Ceratias holboelli Krфyer 1844 - big deepsea angler Cryptopsaras couesi Gill 1883 - small deepsea angler

f. Himantolophidae - footballfishes

Himantolophus groenlandicus Reinhardt 1837 - Atlantic footballfish

f. Ogcocephalidae - batfishes

Dibranchus atlanticus Peters 1875 - Atlantic batfish 


\section{KEYS}

\section{Key to MAJOR CATEGORIES}

1 Jaws absent; fins without rays, paired fins absent; body elongate and snake-like; skin smooth, with one or 7 pairs of pore-like gill openings; a single median nostril; length to about 3 feet. Lampreys and hagfishes, class Marsipobranchii (p.21)

Articulated jaws present, lower jaw movable; typically with paired pectoral and pelvic fins ..........

2 Gill openings slit-like, 5 pairs, either on sides or on under surface of body; body fusiform (sharks), or flattened (rays); skin more or less rough with small and/or large spines, never with overlapping scales.

Sharks and rays (class Selachii) ........ 3

One gill opening on each side; separate anal and urinogenital openings (i.e. no cloaca) ................

3 Body shape fusiform (i.e. spindle-shaped or sharklike); gill openings on side of body; caudal fin distinct and heterocercal; teeth usually sharp and strong, sometimes very small.

Sharks, order Pleurotremata ( $p .21)$

Body shape flattened dorso-ventrally with gill openings on lower surface; pectoral fins broad and winglike, attached throughout length to head and body; tail rod-like.

Rays, order Hypotremata (p.25)

4 Operculum a flap of skin; caudal fin ending in a point; no distinct anal fin; skin smooth or denticulate; mouth inferior, with 2 pairs of plates in upper jaw and one pair in lower jaw; males with club-shaped clasper on forehead; skeleton cartilaginous, without distinct vertebral centra.

Chimaeras, order Chimaeriformes (p.28)

Operculum typically a bony flap; caudal fin various; 
distinct anal fin usually present; body usually covered with overlapping scales, sometimes naked, or plated; highly variably in body shape; skeleton ossified (except in sturgeons).

Bony fishes, class Pisces (Osteichthys) (p.28)

Key to class MARSIPOBRANCHII

Three pairs of barbel-like tentacles about mouth and nostrils; one gill opening on each side, far behind head; mouth not cup-like.

Northern hagfish, Myxine glutinosa

No barbels on head; 7 distinct gill openings on each side of head; mouth cup-like and lined with horny teeth (in adults).

Sea lamprey, Petromyzon marinus

\section{Key to Order PLEUROTREMATA - sharks}

1 Anal fin present $\ldots \ldots \ldots \ldots \ldots \ldots \ldots \ldots \ldots \ldots \ldots \ldots \ldots \ldots \ldots \ldots \ldots$

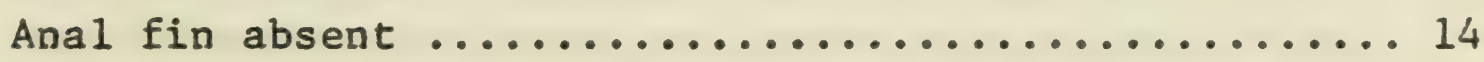

2 Head greatly expanded laterally; eyes located at the lateral extremities.

Smooth hammerhead, Sphyrna zygaena

Head not greatly expanded or enlarged laterally; body fusiform and typically shark-like ............... 3

3 Dorsal lobe of caudal fin greatly enlarged, as long as head and body combined.

Thresher shark, Alopias vulpinus

Dorsal lobe of caudal fin nearly equal in size to lower lobe, or only 2 or 3 times larger ........... 4

4 Gill slits or openings greatly enlarged, the first pair 
nearly meeting over the throat, and all 5 seeming to almost sever the head; teeth minute and numerous; well developed lateral keels on caudal peduncle. Basking shark, Cetorhinus maximus

Gill slits of moderate size, not extending almost around body; teeth not minute but well developed (smooth and pavement-like in Mustelus canis) .......

5 Origin of first dorsal fin distinctly posterior to origin of pelvic fins.

Deepsea cat shark, Apristurus profundorum

Origin of first dorsal fin anterior to the origin

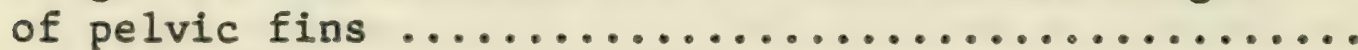

6 Teeth smooth and pavement-1ike; 2 dorsal fins, the 2nd almost as large as the first; origin of first dorsal overlapping posterior quarter of pectoral fin; spiracle below and behind posterior corner of eye.

Smooth dogfish, Mustelus canis

Teeth sharp and pointed; 2 dorsal fins, the first larger than 2 nd, the 2 nd sometimes quite small (2nd dorsal only slightly smaller than first dorsal in

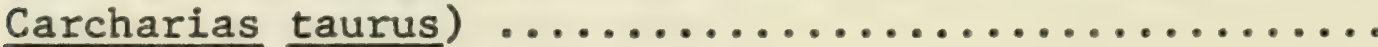

7 First dorsal fin only slightly larger than 2 nd and distinctly behind pectoral fins, free edge of first dorsal overlapping origin of pelvic fins.

Sand shark, Carcharias taurus

First dorsal fin obviously larger than 2 nd dorsal

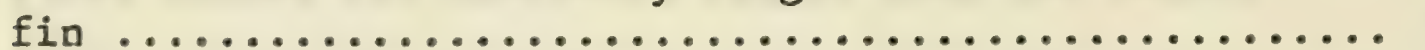

8 Caudal peduncle and caudal fin with one or more distinct lateral or horizontal keels .............. 9

Caudal peduncle without distinct lateral keel ....... 10

9 A second smaller lateral keel below primary keel, on 
lower lobe of caudal fin; teeth in adults with lateral cusps, one on each side of main cusp, these lateral cusps not obvious in young.

Porbeagle, Lamna nasus

No secondary keel below primary keel; teeth without

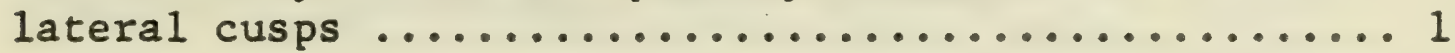

10 Teeth in upper and lower jaws without conspicuous serrations, margins entire; anal fin origin distinctly anterior to origin of 2 nd dorsal fin.

Atlantic sharpnose shark, Rhizoprionodon terraenovae

Teeth in upper and lower jaws with conspicuous serrations (lower teeth of Prionace often smooth or finely serrate); 2nd dorsal fin origin over, or slightly in advance of, anal fin origin ........... 12

11 Teeth slender and awl-like, the anterior teeth long and recurved; origin of dorsal fin wholly posterior to pectoral fins.

\section{Mako, Isurus oxyrinchus}

Teeth broad and triangular, the margins strongly serrated, alike in both jaws, providing straight cutting edges; origin of dorsal fin overlapping posterior portion of pectoral fins.

White shark, Carcharodon carcharias

12 First dorsal fin set far back, nearer pelvic than pectoral fins; pectoral fins long, about 3 times as long as broad; no prominent ridge on dorsal surface between dorsal fins; upper parts of body brilliant blue in colour.

Blue shark, Prionace glauca

First dorsal fin nearer pectoral than pelvic fins, its origin overlapping posterior margin of pectoral fin; length of pectorals moderate, less than 3 times as long as broad; a dorsal ridge present between the

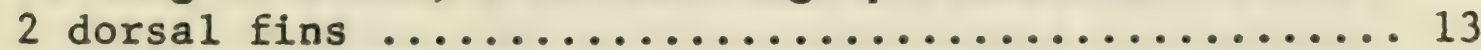


13 Dorsal fin apex broadly rounded; posterior tip of anal fin long, reaching nearly to lower precaudal pit; posterior margin of lower caudal lobe with convex outline; tips of dorsal, pectoral and caudal fins often white.

Whitetip shark, Carcharhinus longimanus

Dorsal fin apex pointed; posterior tip of anal fin relatively short, not reaching nearly to lower precaudal pit; ridge between dorsal fins well developed. Dusky shark, Carcharhinus obscurus

14 Dorsal fins without conspicuous spines at origin. Greenland shark, Somniosus microcephalus

Dorsal fins each with a spine at the origin, spine sometimes concealed by skin (especially in Centros-

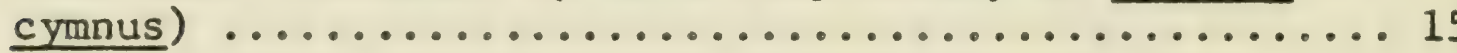

15 Teeth in upper and lower jaws alike ............ 16

Teeth in upper and lower jaws not alike .......... 17

16 Upper and lower teeth quadrangular, one cusp directed outward to form an almost continuous cutting edge; dorsal fin spines rounded; trailing edge of upper caudal lobe entire; colour of body usually gray with light spots; small sharks about 3 feet in length.

Spiny dogfish, Squalus acanthias

Upper and lower teeth each with 3 to 5 triangular cusps; dorsal fin spines deeply grooved; trailing edge of upper caudal lobe notched; colour uniformly dark brown to black; small sharks 2 to 3 feet in length.

\section{Black dogfish, Centroscyllium fabricil}

17 Teeth in upper jaw with only one cusp; dorsal fin spines concealed by skin; body covered with flat overlapping denticles.

Portuguese shark, Centroscymnus coelolepis

Teeth in upper jaw with 5 erect cusps; dorsal fin 
spines conspicuous; body covered with distinct skin spines.

Rough sagre, Etmopterus princeps

Key to order HYPOTREMATA - rays

1 A distinct caudal fin present in addition to 2 obvious dorsal fins; tail or caudal portion thick and short; skin soft, naked and smooth.

Atlantic torpedo, Torpedo nobiliana

No distinct caudal fin; dorsal fin present or absent (stingray); body and tail with small or large tubercles

2 No dorsal fin on tail or body; tail long, thin and with one, 2 or 3 long, well developed, serrated spines on the dorsal surface, nearer the origin than the tip; tail with thorny tubercles.

Roughtail stingray, Dasyatis centroura

One or 2 dorsal fins on distal or proximal portion

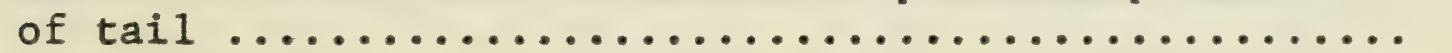

3 Tail thin, whip-like and with one dorsal fin on proximal portion; body with 2 fins on front of head, projecting forward like ears or horns (cephalic fins). Atlantic manta, Manta birostris

Tail not whip-like and with 2 dorsal fins on distal portion; body without cephalic fins; body and tail with small or large spiny tubercles (Rajidae) ....... 4

4 Dorsal fins separate at base; anterior outline of snout usually pointed with angle of less than $90^{\circ}$ (․ radiata has angle about $110^{\circ}$ ) .............. 5

Dorsal fins joined at base; anterior outline of snout obtuse or blunt, $90^{\circ}$ or greater ................. g

5 Mucous pores on ventral surface marked with black 
pigment lending blotchy appearance; no large thorns on back; tail with 3 rows of large spines.

Barndoor skate, Raja laevis

Mucous pores on ventral surface not marked with black pigment; thorns on back large and/or sma11; large

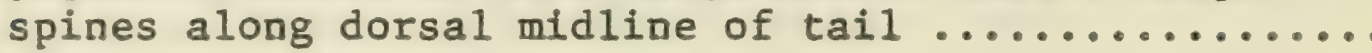

6 No more than 10 large spines along tail posterior to axils of pelvic fins; snout outline blunt (angle about $\left.110^{\circ}\right)$; teeth in $36-46$ rows.

Thorny skate, Raja radiata

More than 10 spines along midline of tail posterior to axils of pelvic fins; snout usually less than $90^{\circ}$.

7 No large spines on body; large spines on midline of tail only, 21-26 in number, posterior to axils of pelvic fins.

$$
\text { Spinytail skate, Raja spinicauda }
$$

Large spines on midline of body and tail and about eyes $\ldots \ldots \ldots \ldots \ldots \ldots \ldots \ldots \ldots \ldots \ldots \ldots \ldots \ldots \ldots \ldots . \ldots \ldots$

824 to 31 large spines along midline of body and tail from nape to first dorsal fin; teeth in 56-66 rows. Jensen's skate, Raja jenseni

47 to 51 large spines along midline of body and tail from nape to first dorsal fin; teeth in 47-50 rows. White skate, Raja lintea

9 Lower surface of disc almost uniform dark brown, darker than upper surface.

$$
\text { Abyssal skate, Raja bathyphila }
$$

Lower surface of disc light in colour, usually white; upper surface distinctly darker than lower surface ... 10

10 A distinct row of spines originating at nape and extending along midline of body and tail, body other- 
wise has mainly small spines $\ldots \ldots \ldots \ldots \ldots \ldots \ldots \ldots \ldots \ldots$

No distinct row of spines along midline of body and seldom on midline of tail; body otherwise with small

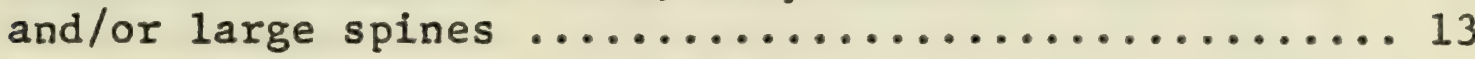

11 Spines along midline of body and tail diminishing in size posteriorly, becoming more or less indistinguishable at $2 / 3$ distance from origin; tail with small spines or prickles only; spines more prominent on young but these have one or 2 conspicuous pale cross bars on tail near base; snout blunt, having an angle of greater than $90^{\circ}$.

\section{Smooth skate, Raja senta}

Spines along midline of body and tail, well developed and conspicuous but not obviously diminishing in size

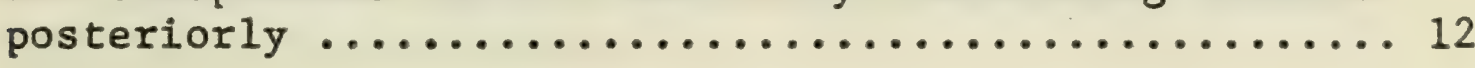

12 Snout blunt, having an angle greater than $90^{\circ}$; males attain length of about 21 inches (Gulf of St. Lawrence and southward).

Little skate, Raja erinacea

Snout sharp, having an angle of less than $90^{\circ}$; males mature at about 38 inches (Northern Labrador and Greenland waters).

$$
\text { White skate, Raja lintea }
$$

13 Body generally with only small spines or prickles but a large spine in front of each eye and spiracle and one or 2 on each shoulder; tail generally without large spines; teeth in 54-56 rows.

Soft skate, Raja mollis

Generally with large and/or small spines on body and tail, body without unique row of midline spines; tail generally with some well developed and conspicuous

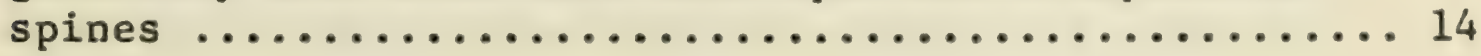

14 Teeth in upper jaw in 30-38 rows; tail usually with a series of rows of large spines extending onto the 
body; tail long, from centre of cloaca to tip 1.3 to 1.6 times as great as the distance from centre of cloaca to snout; tail even longer in young. Round skate, Raja fyllae

Teeth in upper jaw in more than 38 rows $(38-110)$; tail spines variable but not usually in midline (except in young of erinacea); tail length from centre of cloaca to tip 1.3 times or less than the distance from centre

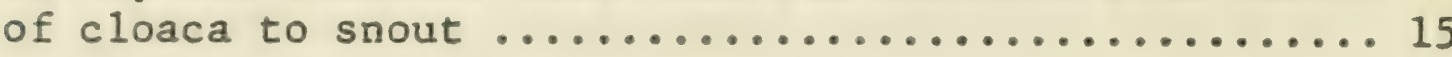

15 Teeth in upper jaw in 38-64 rows, usually less than 54 ; males mature at length of 16-18 inches.

Little skate, Raja erinacea

Teeth in upper jaw in $72-110$ rows, usually 90-100; males mature at length of 26 inches or more.

Winter skate, Raja ocellata

\section{Key to family CHIMAERIDAE}

1 Snout short and rounded; claspers of males bifid (forked) or trifid.

Deepwater chimaera, Hydrolagus affinis

Snout long and pointed; claspers of males simple and

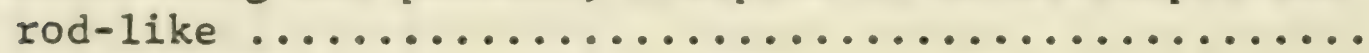

2 Dental plates with knobs and ridges on surface; no denticles on upper margin of caudal fin. Longnose chimaera, Harriotta raleighana

Dental plates smooth or nearly so; a series of rounded knobs or denticles on upper margin of caudal fin. Knifenose chimaera, Rhinochimaera atlantica

Key to orders and families of BONY FISHES

There are a large number of fishes in this category, approximately 20,000 species, varying greatly in size and shape. Compare, for instance, the seahorse 
and the cod, or a stickleback and a halibut. A key to the identification of the major groups, while it may be difficult to follow at times, will assist in the identification by enabling the reader to determine if the specimen in hand is a member of the smelt family, cod family, mackerel-like fishes, etc. Identification to species can be accomplished by referring to the page following the family or group name.

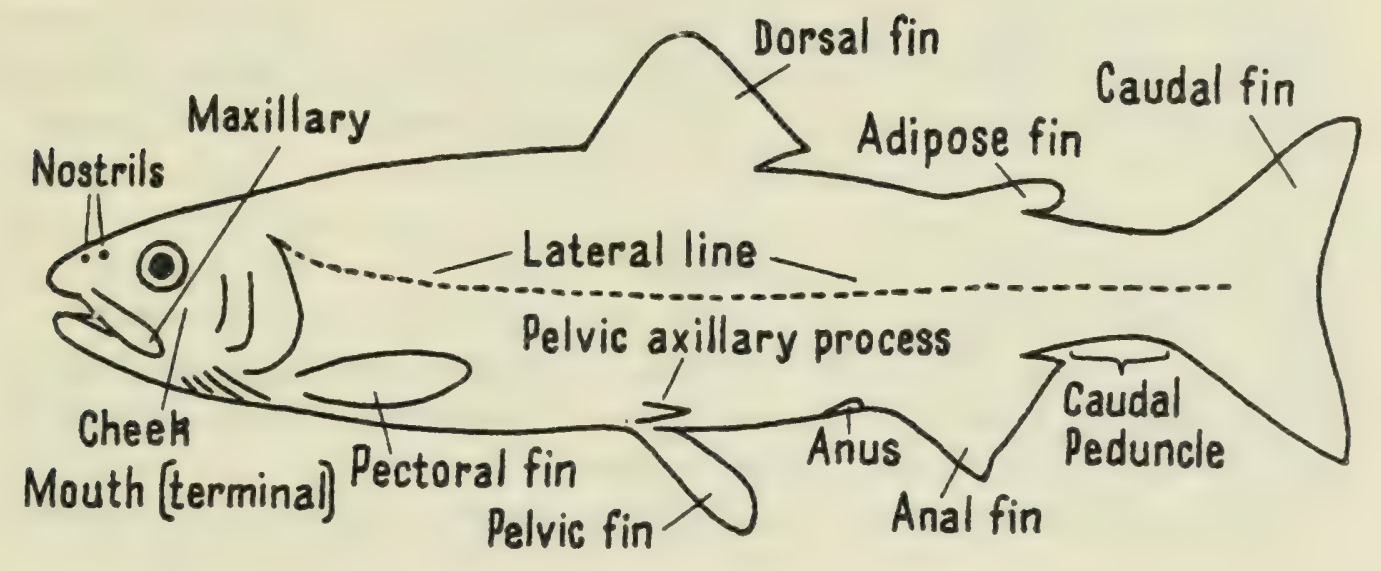

Figure 1. Names of body parts of a bony fish (salmonid)

1 Caudal or tail fin heterocercal (shark-like), i.e. dorsal lobe distinctly larger than ventral lobe; 5 longitudinal rows of bony plates along body; skeleton cartilaginous; mouth inferior, preceded by 4 barbels. Sturgeons, family Acipenseridae (p.42)

Caudal fin not obviously heterocercal, but when present is nearly or quite homocercal ..................

2 Caudal fin abbreviate-heterocercal, i.e. the scaled peduncle extends more posteriorly above than below but fin nearly symmetrical; body covered with thick rhombic plates; dorsal and anal fins located far back, about equidistant from the snout; jaws long, narrow and heavily toothed.

Gars, family Lepisosteidae

Caudal fin not abbreviate-heterocercal, nearly or quite 
homocercal when present; body with overlapping scales, bony rings or plates, prickles or spines, or naked ...

3 Body strongly compressed laterally and asymmetrical, with both eyes on one side, eyed side uppermost and pigmented; lower side unpigmented or nearly so.

Flatfishes, order Heterosomata (p.83)

Body shape variable but symmetrical, usually of conventional shape; one eye on each side of head; (dorsoventral flattening occurs in some pediculate fishes)..

4 Anterior dorsal fin spine(s) located on head and modified and elongated to form an illicium or movable fishing lure (anglerfishes), or this spine modified to a short stubby projection on snout; pectoral fins usually stalked and limb-like.

Anglerfishes and batfishes, order Pediculati (p.87)

Anterior dorsal fin spines not modified to form an

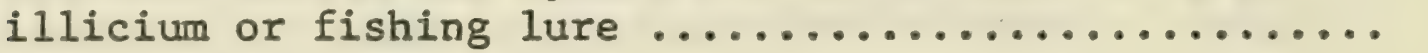

5 Upper jaw prolonged into a stiff hard process, like a spear; lower jaw pointed but much shorter and not spear-like.

Swordfishes and spearfishes, families Xiphiidae and Istiophoridae (p.71)

Upper jaw alone not prolonged into spear-like process (but both upper and lower jaw may be prolonged) ......

6 Lower jaw prolonged and extended in a spear-like process (its length greater than head length).

Halfbeaks, family Hemiramphidae

Lower jaw alone not prolonged and spear-like ........ 7

7 Pelvic fins present (although sometimes reduced to a few rudimentary spines) ...................... 8

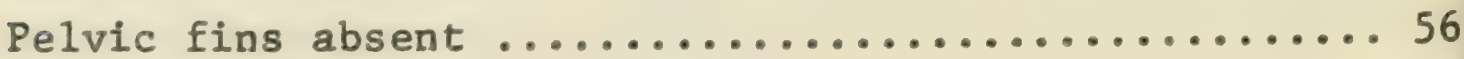


8 Photophores or luminescent organs present; usually small fishes, 12 inches or less in length ......... 9

Photophores absent; small and large fishes ........ 10

9 Body elongate; dorsal fin placed far back very near caudal fin, usually directly over anal fin except in Chauliodontidae and Idiacanthidae; eye small; mouth large and with long, fang-like teeth; often a single, long barbel attached beneath lower jaw; or if body not elongate and without a barbel, then body very deep and mouth nearly vertical (Sternoptychidae), or maxillary long and with edge of maxillary toothed (Gonostomatidae).

Suborder Stomiatoidea (p.48)

Body not particularly elongate; dorsal fin about equidistant from head and caudal fin, its origin distinctly in advance of anal fin; eye large; mouth large but without large, pointed teeth; no barbel beneath head; a fragile adipose fin often present.

Lanternfishes, family Myctophidae (p.51)

10 Adipose fin present, pelvic fins abdominal in position; all fins with soft rays; scales cycloid when present.. 11

No adipose fin; pelvic fins jugular, thoracic or abdominal; fins with soft and/or spinous rays ....... 15

11 Rayed dorsal fin absent; adipose fin only on back. Daggertoothfishes, family Anotopteridae

Rayed dorsal fin present in addition to adipose fin .. 12

12 Pectoral fin originating on side of body close to operculum, the upper ray greatly prolonged, filamentous, extending to caudal fin (other species of this family may have greatly prolonged first ray of pelvic or lower ray of caudal fin).

Feelerfishes, family Bathypteroidae

Pectoral fin inserted near ventral surface and without prolonged rays, upper ray longest and adjoining rays 
13 Dorsal fin about midpoint of body; fins of normal size; body not greatly elongated and not strongly compressed laterally; jaws not beak-like; eye in anterior part of head.

Salmon-like fishes, suborder Salmonoidea ( $p .44)$

Dorsal fin originating either above pectoral fins or behind centre of body and over pelvic fins; body elongate and compressed laterally; jaws beak-1ike; eye on or behind centre of head ................ 14

14 Dorsal fin long and sail-like, originating over pectoral fins and extending to above anal fin; teeth well developed.

Lancetfishes, family Alepisauridae (p.55)

Dorsal fin originating over pelvic fins behind midpoint of body; all fins greatly reduced in size.

Barracudinas, family Paralepididae (Sudidae) (p.54)

15 An oval shaped, sucking disc on top of head, the disc with central midrib and lateral branches.

Sharksuckers, family Echeneidae (p.85)

No sucking disc on top of head ................. 16

16 Pelvic fins abdominal .................... 17

Pelvic fins thoracic or jugular ............... 27

17 Fins soft rayed; scales cycloid when present ....... 18

Fins with one or more stiff spines; scales usually

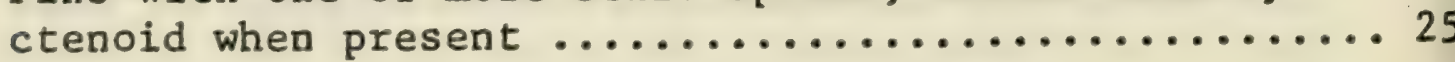

18 Jaws prolonged (or head elongate as in Fistulariidae), or if not, pectoral and pelvic fins greatly expanded.. 21 Jaws and head of conventional shape; paired fins not 
obviously enlarged and wing-like

19 Dorsal fin located midpoint of back; scales obvious;

pelvic axillary process present; silvery fishes.

Herring-like fishes, suborder Clupeoidea ( $p .42)$

Dorsal fin located in posterior position on back; no pelvic axillary process .................... 20

20 Head scaled; body not strongly compressed laterally; body scaled but no obvious lateral line. Topminnows, family Cyprinodontidae (p.57)

Head and body naked or, if scaled, with lateral line; body laterally compressed.

Smoothheads, family Alepocephalidae ( $p .44)$

21 Gape small, snout greatly extended; small mouth at apex of long snout; a hair-like filament extending from centre of caudal fin.

Coronetfishes, family Fistulariidae

Gape moderate; no hair-like filament extending from caudal fin .............................. 22

22 Upper and lower jaws produced and slender $\ldots \ldots \ldots \ldots 23$

Upper and lower jaws not produced conspicuous 1 y ..... 24

23 Teeth weak; dorsal and anal fins low or close-cropped, each with 4-8 finlets.

Sauries, family Scomberesocidae

Teeth moderately strong and needle-like in both jaws; dorsal and anal fins higher anteriorally; no finlets.

Needlefishes, family Belonidae

24 Pectoral fins greatly enlarged, the tips extending to or beyond dorsal fin insertion; pelvic fins also 
enlarged.

Flyingfishes, family Exocoetidae (p.57)

Pectoral and pelvic fins of normal size, tips of pectoral fin reaching origin of dorsal fin at most ... 25

25 No caudal or tail fin; body elongate and tapering to a point; a series of short but well developed spines on back.

Tapirfishes, order Heteromi (p.57)

Caudal or tail fin present; body typically fish-like.. 26

26 Skin naked or with bony plates but no overlapping scales; soft dorsal fin preceded by isolated spines; pelvic fin reduced mainly to a strong spine. Sticklebacks, family Gasterosteidae (p.58)

Overlapping scales present; soft dorsal fin preceded by a separate spiny dorsal fin of 4 slender spines; pelvic fin of one spine and 5 soft rays.

Mullets and silversides, suborder Mugiloidea (p.77)

27 Fins without spines or stiff rays; all rays branched and/or soft rayed; no spines on head ............. 28

Stiff spines* or spine-like branched rays in dorsal, anal or pelvic fins, and sometimes on head and gill

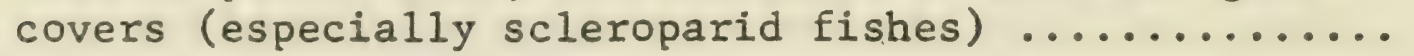

28 Dorsal and anal fins long and continuous with caudal fin; no separate caudal fin.

Eelpouts, family Zoarcidae (p.75)

Dorsal and anal fins distinct from caudal fin, dorsal

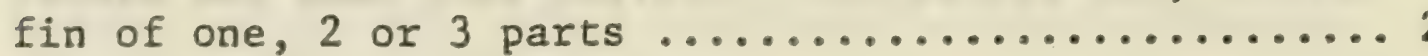

*Sometimes branched (i.e. "soft") rays are very stiff and spine-like as in Macrouridae. 
29 Dorsal fins usually 2 or 3 (only Brosme has one); anal fins one or 2; often chin barbel present; often with filamentous fin rays; rather heavy bodied fishes. Cod-like fishes, order Anacanthini (p.59)

Dorsal and anal fins single and long; caudal forked; body laterally compressed and colourful ........... 30

30 Pelvic rays 14-17; body disc-shaped, silvery with red fins; oceanic.

Opahs, family Lamprididae

Pelvic rays 6-7; dorsal fin commencing over head; caudal fin widely forked; body elongate and of many hues.

$$
\text { Dolphins, family Coryphaenidae }
$$

31 No true caudal fin, body tapering to a pointed tail; snout distinctly projecting.

Grenadiers, rat-tails, family Macrouridae (p.63)

A distinct caudal fin present $\ldots \ldots \ldots \ldots \ldots \ldots \ldots . \ldots \ldots$

32 A series of dorsal and anal finlets (distinct small fins) behind the 2 median fins $\ldots \ldots \ldots \ldots \ldots \ldots \ldots, 33$

No dorsal or anal finlets $\ldots \ldots \ldots \ldots \ldots \ldots \ldots \ldots \ldots \ldots$

33 Lateral line well developed; skin smooth; scales small; dorsal spines well developed and high in front on caudal peduncle and low posteriorly.

Mackerels, family Scombridae ( $p .70)$

Lateral line faint or absent; scales larger and smooth or with sharp spines; dorsal spines more or less weakly developed, widely spaced, uniformly low.

Snake mackerels, family Gempylidae (p.69)

34 A series of bony plates with thorn-like points on both sides at base of dorsal and anal fins and along sides 
or midline of belly; body laterally compressed and discshaped.

Dories, order Zeomorphi (p.65)

No bony plates along dorsal and ventral margins of

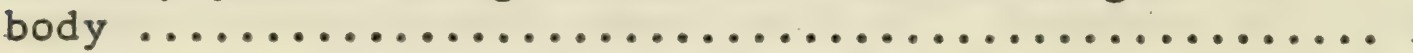

35 Pelvic fin with one spine and 6 ( 5 in Diretmus) or more soft rays, (if no spine, with 2 long throat barbels); pelvic fin base usually behind pectoral fin base; oceanic forms, rare in this region.

Berycoid fishes, order Berycomorphi (p.64)

Pelvic fin with one spine and 5 or fewer soft rays; pelvic fin base usually under or in advance of pectoral

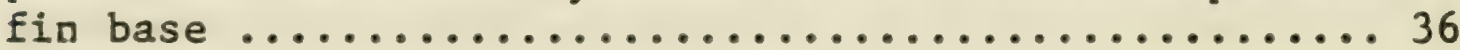

36 Body completely covered with rows of hard overlapping plates; head large; small, slewder fistas under 8 inches long.

Poachers and alligatorfishes, family Agonidae (p.81)

Body scaled, naked or with dermal prickles; spinyrayed fishes of variable shape and size ........... 37

37 Pectoral fins enlarged and wing-like, extending to middle of 2 nd dorsal fin or beyond; head with bony armour

Pectoral fins more or less normal or of conventional shape or somewhat reduced $\ldots \ldots \ldots \ldots \ldots \ldots \ldots \ldots . .39$

38 Pectoral fins extending to beyond insertion of 2 nd dorsal fin, lower rays longest; gill cover with long, spiny backward extension.

Flying gurnards, family Dactylopteridae

Pectoral fins extending to about middle of 2 nd dorsal fin, the lower 3 rays shortest, free of membrane and somewhat thickened.

Searobins, family Triglidae (p. 77) 
39 A single, fleshy adipose fin, atop head and in front of dorsal fin.

Tilefishes, family Branchiostegidae

No fleshy adipose fin atop head .............. 40

40 Body and head entirely naked and smooth, usually uniformly black in colour; caudal fin forked; pelvic fins of normal size, thoracic, of one spine and 5 soft rays.

Black swallowers; family Chiasmodontidae

Body normally scaled or with scattered tubercles or spines on body or head; caudal fin rounded, truncate

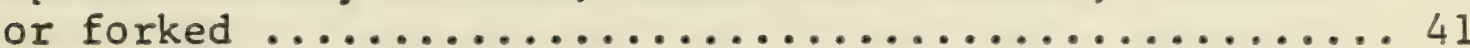

41 Anal fin rays soft and flexible, not preceded by short, stiff spines; pelvic fin rays 3 ; body tadpole-shaped. Sculpins, family Cottidae ( $p .78)$

Anal fin preceded by 2 to 4 stiff spines, sometimes detached from anal fin; pelvic fin rays usually of one spine and 5 soft rays, sometimes fewer; body not

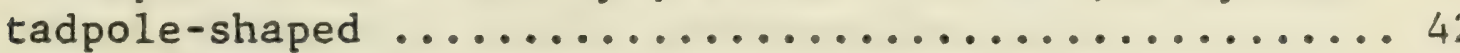

42 Pelvic fin reduced, of one spine and one to 3 soft rays; body elongate; body depth into length 6 or more. Blenny-like fishes, suborder Blennioidea ( $\mathrm{p} .72)$

Pelvic fin of one spine and 5 soft rays; body somewhat laterally compressed, roughly 3 times as long as deep. 43

43 Anal fin preceded by one or 2 spines (these sometimes become inconspicuous with age) $\ldots \ldots \ldots \ldots \ldots \ldots \ldots 4$

Anal fin preceded by 3 or 4 spines (these sometimes becoming partly obscured by skin) ..............448

44 Two prominent chin barbels, red in colour; pelvic axillary scale present.

Surmullets, family Mullidae

No chin barbels ............................ 45 
45 A single dorsal fin, slender spines combine with fin and are not readily distinguishable; dorsal, anal and caudal fins falcate; dorsal and anal fins about equal. Pomfrets, family Bramidae (p.68)

Soft dorsal fin preceded by a distinct spiny dorsal fin or by a series of 3 or more short spines; with or

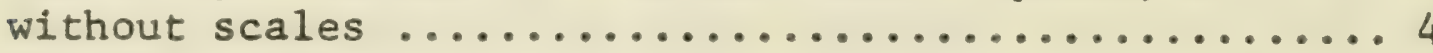

46 Anal fin spines stout and clearly joined to anal fin by membrane; first dorsal fin spiny and distinct, of 10 or more spines.

Drums, family Sciaenidae (p.68)

Anal fin spines usually short and joined to or detached from anal fin; first dorsal fin spiny and of 3 to 8

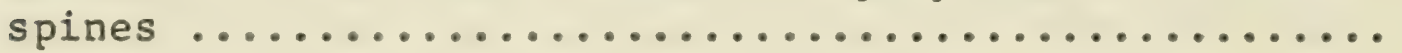

47 Anal fin spines typically short and located in advance of anal fin (16-28 rays); maxillary usually not extending beyond eye posteriorly; caudal peduncle thin and often with lateral keel; pelvic fins well developed. Jacks and pompanos, family Carangidae (p.66)

Anal fin spines also in advance of fin but usually concealed in skin; maxillary extending beyond eye; caudal peduncle not thin but stout and without lateral keel; pelvic fins small.

Bluefishes, family Pomatomidae

48 Head spiny, with one to 5 spines on posterior margin

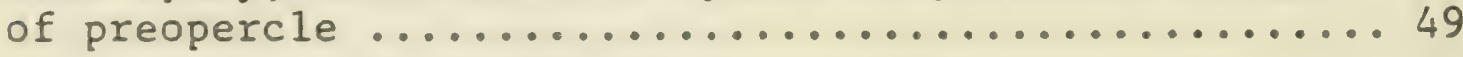

Head not spiny .......................... 50

49 Spiny and soft rayed portions of dorsal fin confluent; preopercle with 4 or 5 spines; body colour red.

Rockfishes, family Scorpaenidae (p.77)

Spiny and soft rayed portions of dorsal fin distinctly separate forming 2 distinct dorsal fins; preopercle with one or 2 spines; body colour dark brown or black. Cardinalfishes, family Apogonidae 
50 Two dorsal fins, the first spiny, the 2nd soft rayed.. 51

A single dorsal fin, the spiny and soft rayed portions broadly joined ........................... 53

51 Head naked or scales confined to opercle only; dorsal fin spines 8 or less (Nomeus on 1y has 11). Butterfishes, family Stromateidae (in part) ( $p .77$ )

Head normally scaled (or, if not, anal fin rays

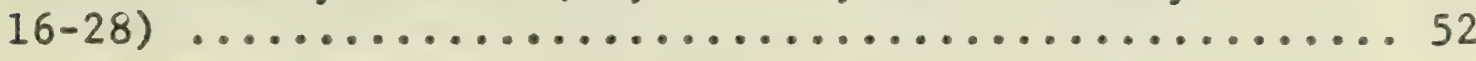

52 Anal fin of 3 spines and 9 or 10 soft rays; peduncle without a lateral keel.

Basses, family Serranidae (p.66)

Anal fin of 2, 3 or 4 spines and 16-30 soft rays, spines sometimes wanting on older specimens; peduncle often with a lateral keel. Jacks and pompanos, family Carangidae (p.66)

53 Dorsal fin spines 16-18; caudal peduncle obviously stout; lower incisor teeth prominent. Wrasses, family Labridae (p.68)

Dorsal fin spines 10-13; caudal peduncle not obviously stout; lower incisor teeth small ............... 54

54 Dorsal fin spines 10; anal fin with 3 spines and 7 soft rays; no pelvic axillary scale.

Basses (Centropristis), family Serranidae (in part) (p.66)

Dorsal fin spines 11-13; anal fin with 3 spines and 10-16 soft rays; pelvic axillary scale present ...... 55

55 Body disc shape; anal fin with 16 soft rays; a black spot on soft dorsal fin base.

Butterflyfishes, family Chaetodontidae

Body deep but not disc shape; anal fin with 10-12 soft 
rays; no black spot on soft dorsal fin.

Porgies, family Sparidae (p.68)

56 A well developed sucking disc on breast, formed from modified pelvic fins.

Lumpfishes and seasnails, family Cyclopteridae (p.82)

No sucking disc on breast $\ldots \ldots \ldots \ldots \ldots \ldots \ldots \ldots 7$

57 First dorsal fin of one or 3 well developed spines; skin hard and scaly or rough like sandpaper; belly often pointed ........................... 58

First dorsal fin not consisting of one or 3 large

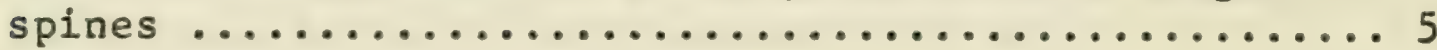

58 First dorsal fin with one large and 2 small spines; body covered with hard, interlocking (often diamondshaped) scales which form an effective armour; teeth well developed and crowded but not fused.

Triggerfishes, family Balistidae (p.86)

First dorsal fin consisting of one large spine only; body covered with small denticles, like sandpaper; teeth well developed but fused; belly often produced ventrally to a point.

Filefishes, family Monacanthidae (p.86)

59 Body covered with bony plates forming a series of bony ridges; mouth small and at end of prolonged snout; fins smal1; gill openings small; small fishes. Seahorses and pipefishes, family Syngnathidae (p.58)

Body not covered with bony plates and ridges .......6 60

60 No distinct caudal fin; dorsal and anal fin rays blending with caudal fin rays, or tail ending in sharp

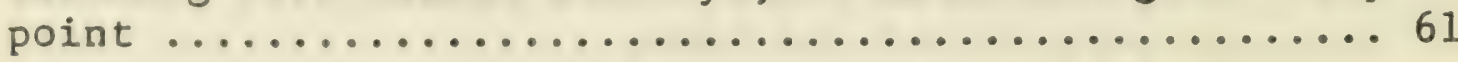

Distinct caudal fin present or body terminating abruptly behind the erect dorsal and anal fins .......66 63 
61 Mouth enormously enlarged, reaching to origin of dorsal fin; eye small and near tip of snout; luminous organs at base of dorsal fin; rare deepsea forns.

Gulpers, family Eurypharyngidae

Mouth of moderate size, or jaws duck-like or slender and extended bill-like; no luminous organs .........6 62

62 Dorsal and anal fin rays soft; body elongate; eyes set in sides of head; mouth not at an acute angle.

True eels, order Apodes (p.55)

Dorsal and anal fia rays spiny; body elongate and compressed; eyes somewhat elevated; mouth at an acute angle.

Wrymouths (Cryptacanthodes), family Stichaeidae (p.73)

63 Body deep or stout, not elongated; mouth small ..... 64

Body elongated; mouth large ...............6 67

64 Body completely encased in a hard and rigid covering, 2 projecting points anteriorly, only caudal peduncle free.

Boxfishes or trunkfishes, family Ostraciontidae

Body not encased in hard covering $\ldots \ldots \ldots \ldots \ldots .65$

65 Body terminating abruptly behind erect dorsal and anal fins; without rayed caudal fin; skin leathery.

Ocean sunfishes or headfishes, family Molidae

A rayed caudal fin present $\ldots \ldots \ldots \ldots \ldots \ldots \ldots \ldots 66$

66 Body deep and laterally compressed; 3 embedded spines before anal fin; scales small.

Butterfishes, family Stromateidae (in part) (p.77)

Body stout, not laterally compressed; without fin spines; without scales but either prickly or body 
covered with stout spines.

Porcupinefishes and puffers, families Tetraodontidae and Diodontidae (p.86)

67 Snout bluntly rounded; upper and lower incisors conical and prominent; dorsal and anal fins well developed and obvious.

Wolffishes, family Anarhichadidae (p.72)

Snout sharply pointed; incisors not obvious ........ 6

68 Fin rays soft, no spines; mouth toothless; a ridge of skin, low on each side along belly; scales small and arranged in oblique rows; small fishes.

Sand lances, family Ammodytidae (p.69)

Fin rays weakly spiny, at times a strong spine behind anus; usually with obvious teeth; scales absent;

deepsea fishes.

Cutlassfishes or hairtails, family Trichiuridae (p.69)

\section{Key to family ACIPENSERIDAE}

Rays in anal fin 19-22; dorsal plates or bucklers widely spaced (up to $1 / 2$ length of a plate); peritoneum blackish; snout short; size smaller (to 36 inches).

Shortnose sturgeon, Acipenser brevirostrum

Rays in anal fin 23-30; dorsal plates or bucklers not widely spaced but crowded; peritoneum pale; snout longer; size large (to 14 feet).

American Atlantic sturgeon, Acipenser oxyrhinchus

\section{Key to families of suborder CLUPEOIDEA}

1 A prominent gular plate present between the 2 arms of the lower jaw; last ray of dorsal fin prolonged and filamentous.

Tarpons, family Elopidae

No gular plate; last ray of dorsal fin not prolonged.. 2 
2 Mouth inferior and small, not extending beyond eye; lateral line present.

Bonefishes, family Albulidae

Mouth terminal or lower jaw somewhat projecting;

lateral line present or absent .................. 3

3 Dorsal fin long, low, located posteriorly; anal fin opposite dorsal fin; lateral line often present.

Smoothheads, family Alepocephalidae (p.44)

Dorsal fin short, located about mid body; no lateral line ................................. 4

4 Mouth terminal and moderate, extending at most to eye or slightly beyond.

Herrings, family Clupeidae (p.43)

Mouth inferior, snout projecting, mouth (gape) very wide, extending far beyond eye; small fishes.

Anchovies, family Engraulidae

Rey to family CLUPEIDAE - herrings

1 Origin of dorsal fin distinctly anterior to pelvic fins; belly outline rounded.

Atlantic round herring, Etrumeus sadina

Origin of dorsal fin not obviously anterior to pelvic fins; belly outline not rounded but more or less

sharp-edged ............................. 2

2 Belly outline not sharply saw-toothed but with a knifeedge; small but definite teeth on roof of mouth.

Atlantic herring, Clupea harengus

Belly outline sharply and strongly saw-toothed; no teeth on roof of mouth .......................

3 Posterior margins of scales almost vertical, not rounded, 
and with fine tooth-like projections.

Atlantic menhaden, Brevoortia tyrannus

Posterior margins of scales rounded and smooth ......

4 Lower jaw fitting into notch in upper jaw when mouth closed; gill rakers more than 55 .

American shad, Alosa sapidissima

Lower jaw projecting, not fitting into deep notch in upper jaw when mouth closed; gill rakers less than 55 .

5 Peritoneum silvery; eye diameter usually greater than snout length*.

Alewife, Alosa pseudoharengus

Peritoneum darkly pigmented; eye diameter usually smaller than snout length.

Blueback herring, Alosa aestivalis

\section{Key to family ALEPOCEPHALIDAE}

Scales (cycloid) present and well developed; lateral line present.

Baird's smoothhead, Alepocephalus bairdii

Scales absent; skin thick; no lateral line.

Atlantic gymnast, Xenodermichthys socialis

\section{Key to families of suborder SALMONOIDEA}

1 Gill membranes separate or free; gill opening wide (branchiostegals 6 or more)

Gill membranes united or joined; gill opening restricted

*Although not recorded from our area, $\underline{A}$. mediocris may be recognized since it has fewer gill rakers on lower part of arch, about 19-21 compared to 30-40 in the alewife. 
(branchiostegals 3 or 4 )

2 Dorsal fin inserted in advance of pelvic fins.

Argentines, family Argentinidae ( $p .47$ )

Dorsal fin inserted over pelvic fins ............. 3

3 Pelvic axillary process well developed; vertebrae at base of caudal fin upturned.

Salmon, trouts, chars, whitefishes, family

Salmonidae (p.45)

No pelvic axillary process; vertebrae not upturned at base of caudal fin.

Smelts, family Osmeridae (p.47)

4 Dorsal fin inserted over pelvic fins.

Blacksmelts, family Bathylagidae

Dorsal fin inserted in advance of pelvic fins.

Argentines (Nansenia), family Argentinidae (p.47)

\section{Key to family SALMONIDAE* - salmon and trouts}

1 Scales sma11, those in lateral line 115-200; teeth we11 developed on jaws and vomer; caudal usually truncate, occasionally forked; young ( 6 inches or less) with dark vertical blotches (parr marks) on sides (except o. gorbuscha).

Salmon, trouts, chars .......... 2

Scales large, those in lateral Iine 100 or less; teeth weakly developed or absent; caudal fin distinctly forked; parr marks absent; colour silvery.

Whitefishes (Coregonus spp.) ....... 7

\footnotetext{
*When in the sea, body pigmentation is usually masked by heavy silvery colouration. The characters enumerated in the key will be evident if the specimen is examined carefully.
} 
2 Anal rays 13-19 (usually 14-16); body and caudal fin with black spots.

Pink salmon, Oncorhynchus gorbuscha

Anal rays $7-12$ (usually $9-11$ ); body and tail fin with

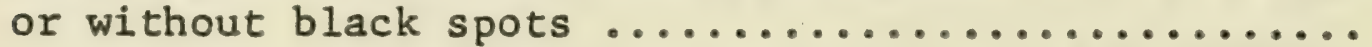

3 Black spots present on head and body (young $\underline{S}$. salar have red spots between parr marks); scales conspicuous, fewer than 165 in lateral line; pelvic and anal fins without white leading edges; vomer flat with teeth extended backward in 2 rows $\ldots \ldots \ldots \ldots \ldots \ldots \ldots . . . .$.

Light spots, not black spots, on body, these spots being pink, red, or cream in colour; lower fins with snow white leading edges; vomer boat-shaped, teeth on

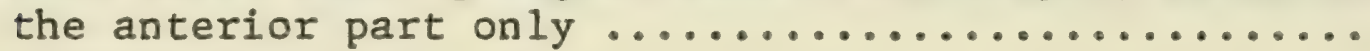

4 Caudal fin distinctly marked with radiating rows of black spots; body never with red spots; anal fin usually with 10 or 11 rays; adipose fin often with a black margin.

\section{Rainbow trout, Salmo gairdneri}

Caudal fin usually unspotted, never with regular rows of black spots; reddish spots sometimes on body; anal fin with 8-11 rays; adipose fin without black margin..

5 Maxillary to below centre of eye in 6-inch fish, seldom far behind eye (except in large males); gill cover with 2 or 3 large spots only; branchiostegals usually 12; dorsal fin rays usually 11 ; vomerine usually not well developed; small fish have red spots between parr marks; no red on adipose fin.

Atlantic salmon, Salmo salar

Maxillary to below last half of eye on 5-inch fish, and extending well beyond eye in larger fish; gill cover usually with many small spots; branchiostegals usually 10; dorsal fin rays usually 9 ; vomerine teeth well developed; rust-red spots sometimes on adults and often on margin of adipose fin.

Brown trout, Salmo trutta 
6 Caudal fin square or nearly so; dorsal and caudal fins with distinct wavy lines or blotches; back usually vermiculated; sides with pink or red spots, many of which have blue borders (young with 8-10 parr marks on sides).

Brook trout, Salvelinus fontinalis

Caudal fin forked; back without spots or markings; dorsal and caudal fins dusky, never with wavy lines or spots; spots on sides cream to pink, sometimes red but never with blue borders (young with 11-13 parr marks).

\section{Arctic char, Salvelinus alpinus}

7 Scales in lateral line more than 90 (91-100); mouth terminal; teeth on premaxillaries, palatines and vomer small but present, even on adults.

Atlantic whitefish, Coregonus sp. 1

Scales in lateral line less than 90 (70-85); mouth inferior, obviously overhung by snout; small teeth on premaxillaries, palatines and vomer of juveniles only. Lake whitefish, Coregonus clupeaformis

\section{Key to family OSMERIDAE}

Well developed fang-like teeth on jaws and especially on tongue; never with longitudinal ridges along sides. American smelt, Osmerus mordax

Teeth on jaws and tongue weak; spawning males with well developed ridges along each side.

Capelin, Mallotus villosus

Key to family ARGENTINIDAE

1 Branchiostegals 3 or 4.

Large-eyed argentine, Nansenia groenlandica

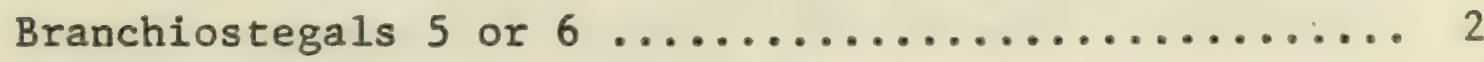

This sea-going whitefish represents an undescribed species currently being studied. 
2 Gill rakers on lower arm of first arch 13 (range 11-15); branchiostegals 6; scales usually with spines; air bladder silvery.

Atlantic argentine, Argentina silus

Gill rakers on lower arm of first arch 6 (range 5-10); branchiostegals 5; scales without spines; air bladder not silvery.

Striated argentine, Argentina striata

Key to families of suborder STOMIATOIDEA

1 Rigid keel, either plate-like or reduced and paired, in front of dorsal fin; body deep and strongly compressed; gape nearly vertical.

Silver hatchetfishes, family Sternoptychidae ( $p .50)$

Without rigid keel in front of dorsal fin; body elon-

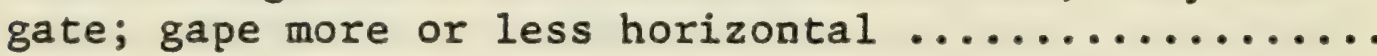

2 Gill rakers present; no barbel. Anglemouths, family Gonostomidae (p.49)

Gill rakers absent, the arches naked or with teeth only; elongate fishes often with barbel under jaw ....

3 Dorsal fin origin far forward, its origin one head length behind head; teeth long, needle-like, lower canines overlapping upper jaw and extending to or above eye; no hyoid or chin barbel.

Viperfishes, family Chauliodontidae

Dorsal fin origin far behind head, 3 or more times the head length; teeth more or less well developed but without bizarre development of lower canines; hyoid barbel usually present (except in Malacosteidae) .....

4 Hyoid or chin barbel absent; no floor in mouth, instead lower jaw connected to hyoid arch by a cord-like strand of tissue; skin without scales or scale-like markings. Loosejaws, family Malacosteidae

Hyoid or chin barbel usually present; lower jaw with a 
floor connecting jaw and hyoid arch

5 Body with scales or scale-like pattern; dorsal fin origin behind anal fin origin and both located far back, behind pelvic fin origin.

Scaled dragonfishes, family Stomiatidae

Body without scales or scale-like markings; dorsal fin origin may be far back behind pelvic fins, or over pelvic fins, or slightly in advance of pelvic fins ... 6

6 Pectoral fins absent; dorsal fin long, its origin in advance of pelvic fins and body midpoint. Sawtailfishes, family Idiacanthidae

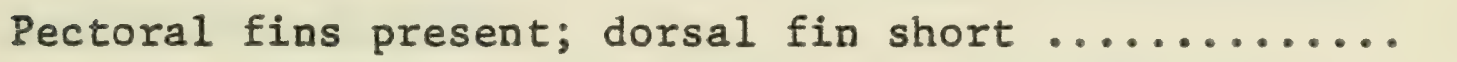

7 Dorsal fin not far back, but in body midpoint position, located over pelvic fins and distinctly in advance of anal fin.

Bighead dragonfishes, family Astronesthidae

Dorsal fin far back, its origin behind pelvic fins; dorsal fin located over anal fin, both fins more or less on caudal peduncle.

Smooth dragonfishes, family Melanostomiatidae (p.50)

Key to family GONOSTOMIDAE

1 Photophores large and obvious and more or less arranged in groups; mouth small.

Müller's pearlsides, Maurolicus muelleri

Photophores on body in continuous longitudinal rows;

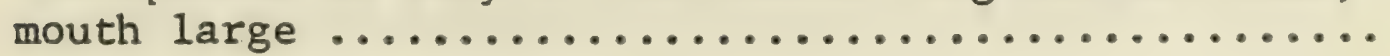

2 Well developed but slender teeth in a continuous series along border of upper jaw, on premaxillary and maxillary; anal rays $21-31$.

Longtooth anglemouth, Gonostoma elongatum

Teeth few in front (absent on premaxillary) increasing 
in size posteriorly; anal rays $16-20$ ( (yclothone sp.).. 3

3 Dark brown in colour.

Veiled anglemouth, Cyclothone microdon

Light in colour with dark speckles.

Brauer's cyclothone, Cyclothone braueri

\section{Key to family STERNOPTYCHIDAE}

1 Dorsal blade not conspicuous externally, visible only as a short, low (paired) keel ia front of dorsal fin; photophores: abdominal 10, supra-abdominal 3, lateral one.

Polyipnus asteroides

Dorsal blade well developed and plainly visible

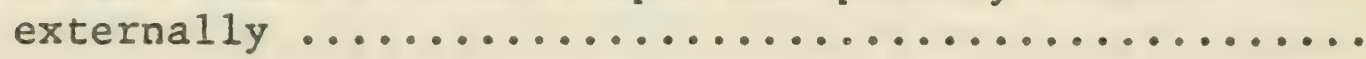

2 Dorsal keel or blade with well defined, ray-like ridges; photophores: abdominal 12, supra-abdominal 6 .

Silver hatchetfish, Argyropelecus aculeatus

Dorsal keel or blade without ray-like ridges and terminating in an acute, backwardly directed tip; photophores: abdominal 10, supra-abdominal none. Transparent hatchetfish, Sternoptyx diaphana

\section{Key to family MELANOSTOMIATIDAE}

1 Vomer without teeth; a continuous luminous line on side extending from behind operculum to anal fin origin, in addition to 2 rows of photophores. Torpedo dragonfish, Grammatostomias dentatus

Vomer toothed; no continuous luminous line on side in addition to photophores .......................

2 Pectoral fins located near mid point of body; teeth 
mainly fixed, depressible anteriorly only; dorsal fin rays $18-20$.

Threelight dragonfish, Trigonolampa miriceps

Pectoral fins located in posterior half of body, near anal fin; teeth depressible; dorsal fin rays 12-15.

Bluenose dragonfish, Melanostomias spilorhynchus

Key to subfamilies and genera of MYCTOPHIDAE ${ }^{1}$

Key to subfamilies

A Anal fin commencing some distance behind insertion of last dorsal ray (only genus Neoscopelus possible).

Subfamily Neoscopelinae

B Anal fin commencing below dorsal or close behind insertion of last dorsal ray.

Subfamily Myctophinae

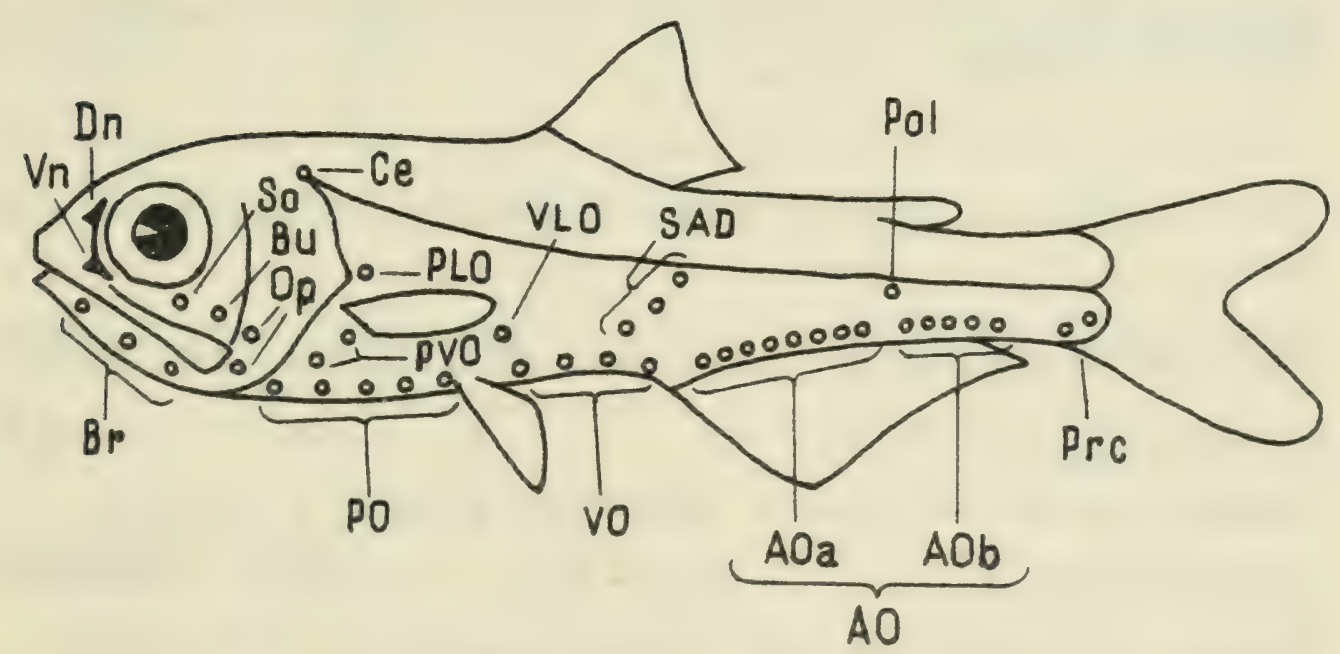

Figure 2. Stylized myctophid showing the designations used for the various photophores.

IAdapted from a more detailed key provided by Mrs. Isobel Radforth. 
Key to genera of subfamily Myctophinae

1 Procurrent caudal rays soft, flexible and never bearing luminous tissue $\ldots \ldots \ldots \ldots \ldots \ldots \ldots \ldots \ldots, 2$

Procurrent caudal rays stiff, spine-like, and may bear

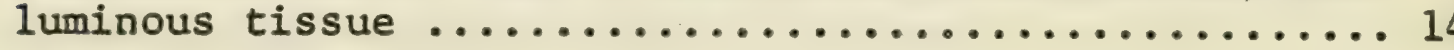

$2 \mathrm{AO}$ in one continuous series; no distinct Pol.

genus Hierops

AO in 2 series; distinct Pol $\ldots \ldots \ldots \ldots \ldots \ldots \ldots \ldots$

3 Some photophores above lateral line area. genus Notolychnus

No photophores above lateral line .............. 4

4 Base of anal fin much longer than that of dorsal .... 5

Base of anal fin shorter or only slightly longer than that of dorsal ............................ 6

5 PLo distinctly higher than upper end of pectoral fin

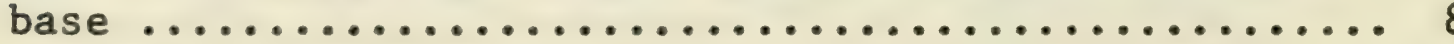

PLO not higher than upper end of pectoral fin base ... 12

6 Supra- or infra-caudal luminous glands present. genus Lobianchia

Supra- or infra-caudal luminous glands not present ... 7

$72 \mathrm{Vn}$, the second appearing as a well defined rounded organ on lower orbital margin. genus Diaphus

$1 V n$, greatly expanded, extending along the entire anterior orbital margin and part of the lower orbital margin. genus Aethoprora 


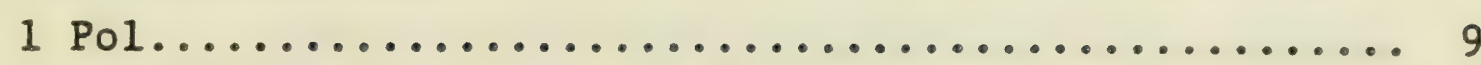

9 PVo horizontal or nearly so, not forming a straight line with first PO ........................ 10

PVO oblique, forming straight line with first PO .... 11

10 2nd Prc elevated.

2nd Prc not elevated.

11 SAO strongly angulated.

SAO in a straight, or almost straight, oblique line. genus Myctophum

12 Narrowest part of caudal peduncle greater than diameter of eye.

genus Loweina

Narrowest part of caudal peduncle less than diameter

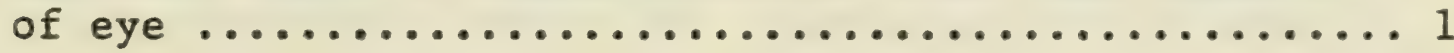

13 Lateral line distinct.

No lateral line.

genus Centrobranchus

14 Photophore groups not distinct. genus Scopelopsis

Photophore groups distinct .................. 15

15 Single supra- and infra-caudal luminous glands present, heavily outlined with black pigment $\ldots \ldots \ldots \ldots \ldots \ldots 16$

No well defined, pigment-outlined supra- and infra-caudal glands 
16 Pelvic fins inserted under dorsal fin origin.

genus Lampadena

Pelvic fins well in advance of dorsal fin origin. genus Taaningichthys

17 Base of dorsal fin longer than that of anal.

genus Notoscopelus

Base of dorsal fin not longer than that of anal $\ldots . .18$

18 One or 2 strong teeth on each side of head of vomer. genus Ceratoscopelus

A patch of small teeth on each side of head of vomer.. 19

19 Scale-like luminous glands at the bases of dorsal, anal and sometimes the pectoral and pelvic fins.

genus Lepidophanes

No scale-like luminous glands at the bases of the dorsal, anal, pectoral or pelvic fins.

genus Lampanyctus

\section{Key to family PARALEPIDIDAE}

1 Body of adults naked except for series of scales along lateral line; teeth in lower jaw well developed in adults. genus Lestidium

Body of adults covered with small scales, and often evident only as scale pockets; teeth in lower jaw of adults short and weak ....................... 2

$\overline{1}$ Although not reported to occur within the area, at least 3 species of this group of barracudinas have been shown to occur east or south of our region (Ege, V., 1953) and may therefore be reported in the future. 
2 Predorsal length in percent of standard length 63.5 to 67.3 ; anal rays $31-34$; vertebrae 83-85.

White barracudina, Paralepis rissoi krфyeri

Predorsal length in percent of standard length 58.0

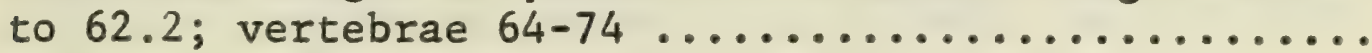

3 Snout length as percent of standard length for juveniles 14.8 to 14.9 , for adults 12.1 to 13.1 ; vertebrae 64-71.

Short barracudina, Paralepis brevis brevis

Snout length as percent of standard length for juveniles 11.3 to 12.0 , for adults 10.3 to 11.8 ; vertebrae $72-74$.

Paralepis coregonoides borealis

\section{Key to family ALEPISAURIDAE}

Snout relatively short, the distance from tip of snout to dorsal fin origin being 9 to 13 percent of standard length in adults; dorsal fin rays usually 42-45; anal fin rays usually 14 or 15 .

Shortnose lancetfish, Alepisaurus brevirostris

Snout relatively long, the distance from tip of snout to dorsal fin origin being 16 to 22 percent of standard length in adults; dorsal fin rays usually 39-42; anal fin rays usually $15-17$.

Longnose lancetfish, Alepisaurus ferox

Key to species of order APODES

1 Pectoral fins absent; dorsal fin origin in advance of circular gill opening.

Green moray, Gymnothorax funebris

Pectoral fins present; dorsal fin origin over or behind gill opening 
2 Jaws prolonged, very slender; body obviously slender; anal opening just behind head or one head length behind. (Nemichthyidae)

Jaws well developed but not strikingly prolonged; body more or less robust; anal opening far behind head ....

3 Dorsal fin origin posterior to origin of anal fin and anal opening; mouth (gape) extending far behind eye. Gray's cutthroat eel, Synaphobranchus kaupi

Dorsal fin origin in advance of anal fin origin and anal opening

4 Dorsal fin origin over posterior margins of pectoral fins.

$$
\text { American conger, Conger oceanicus }
$$

Dorsal fin origin behind posterior margin of pectoral

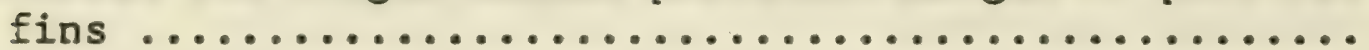

5 Snout extended beyond lower jaw and expanded laterally in front like a duck's bill; mouth extending to below posterior margin of eye.

\section{Duckbill eel, Nessorhamphus ingolfianus}

Snout blunt or pointed but not expanded to resemble duck's bill; mouth terminating before or behind eye... 6

6 Snout blunt; mouth very small, not extending even to anterior margin of eye.

Snubnose eel, Simenchelys parasiticus

Snout more or less pointed; mouth extending to or

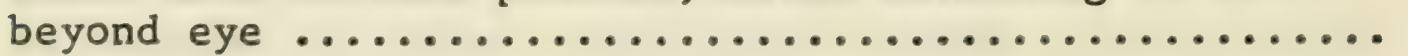

7 Dorsal fin origin far behind head; mouth extending barely behind posterior margin of eye; tip of tail soft. American ee1, Anguilla rostrata

Dorsal fin origin just behind head (within one head 
length); mouth extending considerably behind eye; tip of tail hard.

Snake eel, Omochelys cruentifer

8 Jaws very prolonged, delicate, flexible; dorsal fin origin in advance of anal fin origin and anus.

Atlantic snipe eel, Nemichthys scolopaceus

Jaws prolonged, not delicate; dorsal fin origin behind origin of anal fin and anus.

Stout sawpalate, Serrivomer beani

Key to order HETEROMI

1 Dorsal spines not isolated, but a dorsal fin of 5 graduated spines and 5 soft rays is present.

Backfin tapirfish, Lipogenys gillii

Dorsal spines $(6-34)$ in isolated series along back ... 2

2 Dorsal spines $6-12$.

Largescale tapirfish, Notacanthus nasus

Dorsal spines 27-34.

Shortspine tapirfish, Macdonaldia rostrata

\section{Rey to family EXOCOETIDAE}

Lateral line scales 56-60; dorsal and anal fins pale; ventrals dusky or clear but wi thout spots.

Atlantic flyingfish, Cypselurus heterurus

Lateral line scales 46; dorsal and anal fins with distinct spots.

Spotfin flyingfish, Cypselurus furcatus

Key to family CYPRINODONTIDAE

Gill rakers usually 5, widely spaced and obvious; 
distance from origin of dorsal fin to end of vertebral column, stepped forward from dorsal fin origin, reaches a point about middle of eye.

Banded killifish, Fundulus diaphanus

Gill rakers usually 9 or more, crowded and not obvious; distance from origin of dorsal fin to end of vertebral column, stepped forward from dorsal fin origin, reaches posterior half of operculum.

Mummichog, Fundulus heteroclitus

\section{Key to family SYNGNATHIDAE}

Head oriented at right angle to body; no caudal fin; body tapering to a point and often curled like a watch spring.

Spotted seahorse, Hippocampus erectus

Head in line with body; no caudal fin; body tapering to a point but not curled.

Northern pipefish, Syngnathus fuscus

\section{Key to family GASTEROSTEIDAE}

1 Dorsal spines usually $9(7-12)$, short and inclined alternately to left and right; gill membrane entirely free from isthmus; a median ventral plate present; no bony plates on sides.

Ninespine stickleback, Pungitius pungitius

Dorsal spines $3-6$; gill membrane united to isthmus; usually bony plates along side and between pelvic fins

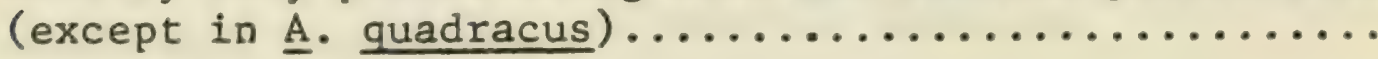

2 Dorsal spines 4 or 5 (rarely 6), last spine attached to soft dorsal, spines inclined alternately to left and right side; a bony stay directed posteriorly from base of each pelvic fin; no median ventral plate.

Fourspine stickleback, Apeltes quadracus

Dorsal spines 3 (rarely 4), last spine not attached to 
soft dorsal, all spines in line; a strong median ventral plate extending posteriorly from pelvic base .... 3

3 Dorsal spines 3 (rarely 4), last spine short; pelvic fin of one spine and one soft ray, spine with one pointed cusp at base; caudal peduncle with a keel; body without round black spots; colour in life green, blue or silvery.

Threespine stickleback, Gasterosteus aculeatus

Dorsal spines 3 (rarely 2); pelvic fin of one spine and 2 soft rays, spine with 2 well developed pointed cusps at base; caudal peduncle keelless; many round black spots along sides; colour in life lemon-yellow. Blackspotted stickleback, Gasterosteus wheatlandi

\section{Key to genera of order ANACANTHINI \\ (families Moridae and Gadidae)}

1 One (Brosme only), 2 or 3 dorsal fins; one or 2 anal fins; vomer usually toothed (Gadidae) ............. 2

Two dorsal fins (base of first dorsal short, 2nd dorsal long); one or 2 anal fins; if one anal fin this often deeply divided; vomer usually toothless (Moridae) .... 14

2 One dorsal and one anal fin only, each joined to caudal and separated from it by a notch; median fins dark toward margin, with white edging ...... genus Brosme

Two or 3 dorsal fins; one or 2 anal fins .......... 3

3 Three dorsal fins; 2 anal fins ................ 4

Two dorsal fins (first dorsal sometimes reduced to a single filament); one anal fin; (2nd dorsal and anal may be deeply notched as in Merluccius) ........... 9

4 Lower jaw projecting to or beyond upper jaw; barbel 
minute or obsolete $\ldots \ldots \ldots \ldots \ldots \ldots \ldots \ldots \ldots \ldots \ldots \ldots \ldots \ldots$

Lower jaw not projecting to or beyond upper jaw (i.e. snout projecting); barbel well developed, sometimes

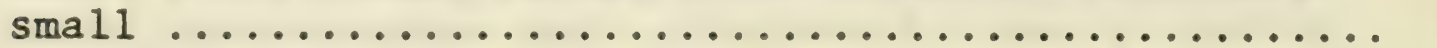

5 Base of first anal fin long, its origin below the origin of first dorsal fin. genus Micromesisteus

Base of first anal fin moderate in length, its origin below origin of 2 nd dorsal fin $\ldots \ldots \ldots \ldots \ldots \ldots \ldots, 6$

6 Scales imbricate (overlapping); pectoral fins extending to insertion of first dorsal only; pelvic fins reduced, less than $3 / 4$ length of pectoral fins.

genus Pollachius

Scales not imbricate; pectoral fins extending to origin of 2 nd dorsal; pelvic fins well developed, more than $3 / 4$ length of pectoral fins. genus Boreogadus

7 Large black blotch on side above pectoral fin; lateral line black; first dorsal fin distinctly pointed. genus Melanogrammus

No large black blotch on side; lateral line light; first dorsal fin rounded $\ldots \ldots \ldots \ldots \ldots \ldots \ldots \ldots \ldots$.

8 Barbel well developed but slender, its length about twice diameter of pupil of eye; eye large, its diameter 4.0 to 5.5 in head length. genus Gadus (p.61)

Barbel short, stout, its length only slightly greater than diameter of pupil; eye small, its diameter 6.2 or more in head length. genus Microgadus

9 First ray in dorsal fin prolonged and thread-like ... 10 First ray in dorsal fin not prolonged ........... 12 
10 Remaining rays in dorsal fin graduated in size and readily visible; no barbels on snout.

genus Urophycis (p.63)

Remaining rays in dorsal fin reduced in size, uniformly short, hair-like and inconspicuous; 2 or 3

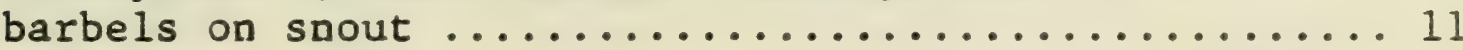

11 Three barbels on snout, 2 lateral and one median; black blotch on posterior portion of both dorsal and anal fins.

genus Enchelyopus

Two barbels on snout, no median barbel; no black blotch on dorsal or anal fins. genus Gaidropsarus (p.62)

12 Pelvic fins consist of 2 filamentous rays only, the longest extending to pectoral tip or beyond.

genus Urophycis ( $p .63$ )

Pelvic fins with 6 or 7 rays, one or 2 may be slightly

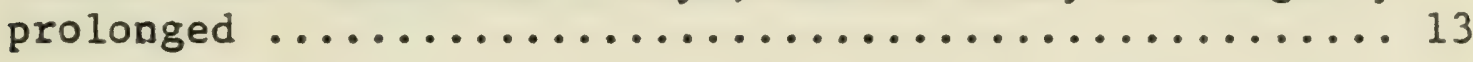

13 Anal rays $37-42$; barbel absent; tip of pectoral fin extending beyond insertion of first dorsal. genus Merluccius (p.62)

Anal rays 55-81; barbel well developed; tip of pectoral fin extending to middle of first dorsal fin or only slightly beyond.

genus Molva ( $p .62$ )

14 Upper jaw projecting beyond lower; snout with a strong lateral shelf-like projection on each side; a small barbel present.

genus Antimora

Lower jaw projecting; no lateral projections on snout; barbel absent. genus Halargyreus

Key to species of GADUS

Body generally spotted; peritoneum leaden-silvery in 
colour.

Atlantic cod, Gadus morhua

Body unspotted; peritoneum uniformly jet black in colour.

Greenland cod, Gadus ogac

Key to species of GAIDROPSARUS

Length of first ray in first dorsal fin 5.9 to 8.5 percent of total length of fish.

Silver rockling, Gaidropsarus argentatus

Length of first ray in first dorsal fin long, 14.0 to 20.3 percent of total length of fish.

Threebeard rockling, Gaidropsarus ensis

\section{Key to species of MERLUCCIUS}

Gill rakers on first gill arch 15-22; lateral line scales 103-130.

Silver hake, Merluccius bilinearis

Gill rakers on first gill arch 9-11; lateral line scales 130-148.

Offshore hake, Merluccius albidus

\section{Key to species of MOLVA}

Rays in 2 nd dorsal fin 69-83; anal rays $70-81$; first dorsal base into 2nd dorsal base 5.3 to 7.5 times; colour uniformly gray to gray brown and without mottling; median fins without white edging; no dark spot at posterior edge of first dorsal fin.

Blue ling, Molva byrkelange

Rays in 2nd dorsal fin 59-70; anal rays 57-66; first dorsal base into 2nd dorsal base 3.5 to 4.5 times; colour usually brown with distinct marbling; median fins with distinct white edging; a dark spot at the 
posterior edge of first dorsal fin.

European ling, Molva molva

Key to species of UROPHYCIS

1 Pelvic fin filaments very long, the first extending nearly to the end of the anal fin, the 2 nd extending well beyond anal fin origin.

Longfin hake, Urophycis chesteri

Pelvic fin filaments not reaching origin of anal fin or, if so, overlapping only first few rays ........ 2

2 First ray of first dorsal fin not prolonged into a filament, upper half of this fin black with white edging; lateral line interrupted by whitish spots.

Spotted hake, Urophycis regius

First ray of first dorsal fin prolonged into a fila-

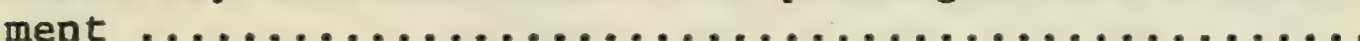

3 Scales on body in about 140 rows; posterior angle of mouth extending to vertical through posterior margin of orbit of eye.

White hake, Urophycis tenuis

Scales on body in about 110 rows or fewer; posterior angle of mouth extending to vertical through posterior margin of pupil of eye.

Squirrel hake, Urophycis chuss

\section{Key to family MACROURIDAE}

1 Snout greatly prolonged, its length nearly twice eye diameter; scales along base of dorsal and anal fins enlarged and scute-like.

Roughnose grenadier, Trachyrhynchus murrayi

Snout length about equal to the eye diameter; scales along bases of dorsal and anal fins not conspicuously 
2 First dorsal fin spine smooth.

Longnose grenadier, Coelorhynchus carminatus

First dorsal fin spine long and serrate ........... 3

3 Anus surrounded by scaleless, black skin and located near pelvic fins; branchiostegal rays $7 \ldots \ldots \ldots \ldots .4$

Anus not surrounded by scaleless, black skin and not located near anal fin; branchiostegal rays $6 \ldots \ldots . .5$

4 Scales small, present along 4 lower branchiostegal rays; pyloric caecae 60 or more. American straptail grenadier, Malacocephalus occidentalis

Scales moderate, absent from branchiostegals and gular region; pyloric caecae less than 30 .

Marlin-spike, Nezumia bairdi

5 First rays of 2 nd dorsal fin in front of anal fin origin; pelvic fin rays not produced; scales large and strong.

Roughhead grenadier, Macrourus berglax

First rays of 2 nd dorsal fin behind origin of anal fin; first pelvic fin ray produced; scales moderate. Rock grenadier, Coryphaenoides rupestris

Key to order BERYCOMORPHI - berycoid fishes

1 A pair of well developed hyoid barbels present. Stout beardfish, Polymixia nobilis

No hyoid barbels present ..................... 2

2 Scales small or minute; gape large, extending well 
behind eye; anterior teeth in lower jaw enlarged, the length greater than eye diameter.

Ogrefish, Anoplogaster cornuta

Scales large; gape moderate; teeth not conspicuously

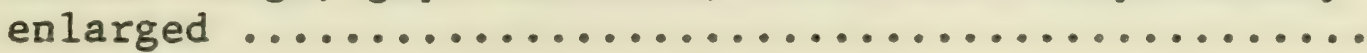

3 Pelvic fin with one thin, blade-like spine and 5 soft rays; body deep and strongly compressed laterally. Spinyfin, Diretmus argenteus

Pelvic fin of one spine and 7-13 soft rays; body more or less elongate, not noticeably deep ............ 4

4 Pelvic fin with one spine and 7 soft rays; scales cycloid.

$$
\text { Bean's blueback, Scopelogadus beanii }
$$

Pelvic fin with one spine and 10-13 soft rays; scales

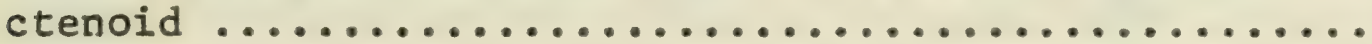

5 Scales in lateral line 63-73; dorsal soft rays 16-19. Alfonsin a Casta Larga, Beryx decadactylus

Scales in lateral line 71-78; dorsal soft rays 13-15. Alfonsin a Casta, Beryx splendens

\section{Key to order ZEOMORPHI}

Large, plate-like spines along bases of dorsal and anal fins and along midline of belly; no spines on sides; mouth large; pectoral fin base in advance of posterior margin of gill cover.

American John Dory, Zenopsis ocellata

Small, thorn-like spines along bases of dorsal and anal fins and 11 or 12 flattened spines on sides; mouth small; pectoral fin base behind posterior margin of gill cover.

Grammicolepid, Xenolepidichthys americanus 
Key to family SERRANIDAE

1 Dorsal fins (first spiny, 2nd soft-rayed) appearing as 2 distinct fins, entirely separate or very weakly

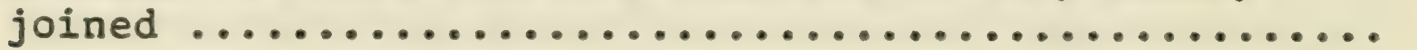

Dorsal fins (spiny and soft-rayed portions) broadly

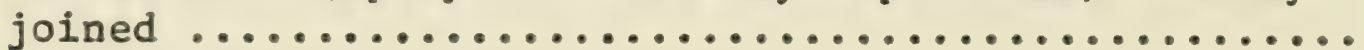

2 Anal fin rays usually 9; anal fin spines not graduated in size, stout, the longest spine $3 / 4$ or more the height of anal fin; body without stripes. White perch, Roccus americanus

Anal fin rays usually 11; anal fin spines graduated in size and slender, the longest spine less than $1 / 2$ the height of anal fin; body with about 7 lateral stripes. Striped bass, Roccus saxatilis

3 Pelvic fins inserted slightly behind pectoral fins; head smooth and without rough crests; first or spiny dorsal fin high anteriorly; posterior spines not greatly shortened; caudal fin emarginate.

Red grouper, Epinephelus morio

Pelvic fins inserted under or slightly in advance of pectoral fins; head with rough crests; first or spiny dorsal fin with longest spines in centre, graduating in size before and after; caudal fin rounded.

Atlantic wreckfish, Polyprion americanus

\section{Key to family CARANGIDAE}

1 Body strongly compressed laterally and noticeably deep; head especially greatly elevated, lending effect of a "Iong face"............................... 7

Body moderately compressed laterally and not markedly deep; head not strongly elevated ................. 2

2 Lateral line with raised specialized scales or scutes, 
forming a distinct ridge, often more prominent posteri-

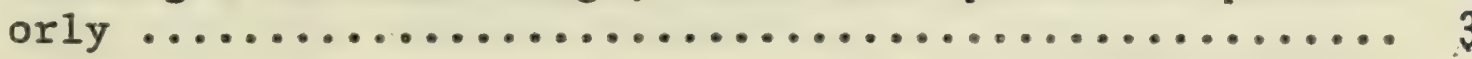

Lateral line without raised specialized scales or scutes $\ldots \ldots \ldots \ldots \ldots \ldots \ldots \ldots \ldots \ldots \ldots \ldots \ldots \ldots \ldots \ldots \ldots . . \ldots \ldots$

3 Maxillary extending to posterior margin of eye or beyond; a black patch on gill cover; pectoral fin falcate. Crevalle jack, Caranx hippos

Maxillary not extending to posterior margin of eye, but terminating in front of or below pupil of eye ....... 4

4 Lateral line strongly arched behind head, arch terminating over, not beyond, pectoral fin; anus located below centre of spinous dorsal fin.

Blue runner, Caranx crysos

Lateral line scarcely arched, gently curved; anus below last ray of spinous dorsal fin, or posterior to

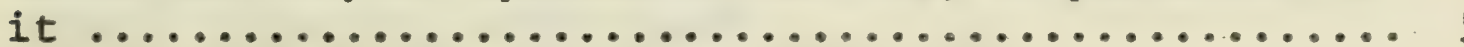

5 Body elongate; distance between pelvic fin tips and anus about equal to body depth.

Mackerel scad, Decapterus macarellus

Body moderately compressed and deep, rather than elongate; pelvic fin tips barely reach anterior edge of anus.

Bigeye scad, Selar crumenophthalmus

6 Dorsal fin spines short, without connecting membrane in adult; mouth smal1; maxillary not quite reaching line through anterior margin of eye.

Pilotfish, Naucrates ductor

Dorsal fin spines moderately developed and connected by membrane; maxillary extending to below pupil of eye. Banded rudderfish, Seriola zonata

7 Anterior rays of soft dorsal and anal fins greatly 
elongated, succeeding rays very short.

Atlantic lookdown, Selene vomer

Anterior rays of soft dorsal and anal fins not elongated; all rays relatively short.

Atlantic moonfish, Vomer setapinnis

Key to family BRAMIDAE

Scales large, 40-50 in mid lateral row.

Bigscale pomfret, Taractes longipinnis

Scales small, about 80 in mid lateral row.

Smallscale pomfret, Brama rayi

\section{Key to family SCIAENIDAE}

Barbels present on lower jaw; mouth somewhat inferior. Black drum, Pogonias cromis

No barbels present on lower jaw; lower jaw distinctly projecting.

Weakfish, Cynoscion regalis

Key to family SPARIDAE

Tips of pelvic fins reaching and overlapping anus; caudal fin lunate, the tips pointed.

Scup, Stenotomus chrysops

Tips of pelvic fins not reaching to anus; caudal fin with shallow fork, tips rounded.

Sheepshead, Archosargus probatocephalus

Key to family LABRIDAE

Base of pelvic fins located below base of pectoral fins; front of head distinctly rounded in lateral view; 
lower half of operculum without scales.

Tautog, Tautoga onitis

Base of pelvic fins located obviously behind base of pectoral fins; front of head distinctly pointed in lateral view; lower half of operculum with scales.

Cunner, Tautogolabrus adspersus

\section{Key to family AMMODYTIDAE}

Dorsal fin rays $57-60$; anal fin rays $28-31$; vertebrae 64-69.

American sand lance, Ammodytes americanus

Dorsal fin rays $62-67$; anal fin rays $32-35$; vertebrae $71-75$.

Northern sand lance, Ammodytes dubius

Rey to family GEMPYLIDAE

Caudal peduncle keeled; dorsal fin spines 7-12.

Escolar, Lepidocybium flavobrunneum

Caudal peduncle not keeled; dorsal fin spines 13-15.

Oilfish, Ruvettus pretiosus

Key to family TRICHIURIDAE

Total dorsal fin rays $91-95$ (spiny rays $38-40$, soft rays 53-55); spinous and soft dorsal fin bases about equal.

Black scabbardfish, Aphanopus carbo

Total dorsal fin rays $147-154$ (spiny rays 45 or 46 , soft rays 102-108); base of spiny dorsal fin $1 / 2$ that of soft dorsal fin.

Frostfish, Benthodesmus simonyi 


\section{Key to family SCOMBRIDAE}

1 Dorsal fins separated by a distance greater than snout length; dorsal fin spines about $9-12 \ldots \ldots \ldots \ldots \ldots \ldots$

Dorsal fins separated by a distance less than snout

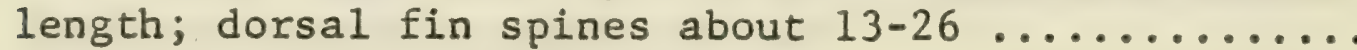

2 Dorsal finlets 8 or 9; anal finlets 7; a median keel on each side of caudal peduncle.

Frigate mackerel, Auxis thazard

Dorsal and anal finlets (each) 5; no median keel on

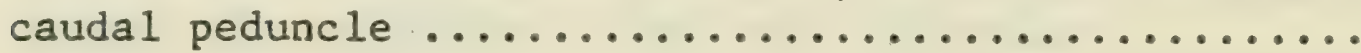

3 Dorsal fin spines 11 or 12 ; no air bladder. Atlantic mackerel, Scomber scombrus

Dorsal fin spines 9 or 10; air bladder present. Chub mackerel, Scomber colias

4 Gill rakers on lower limb of first arch 36-40. Skipjack tuna, Euthynnus pelamis

Gill rakers on lower limb of first arch 7-29 ...... 5

5 Dorsal fin spines 20-22; gill rakers $12-14$.

Atlantic bonito, Sarda sarda

Dorsal fin spines 13-15; gill rakers 15-28; first

dorsal spine about as long as 2 nd and 3 rd (Thunnus)... 6

6 Gill rakers 24-28; pectoral fin length less than $4 / 5$ head length.

Bluefin tuna, Thunnus thynnus

Gill rakers 15-22; pectoral fin length more than $4 / 5$

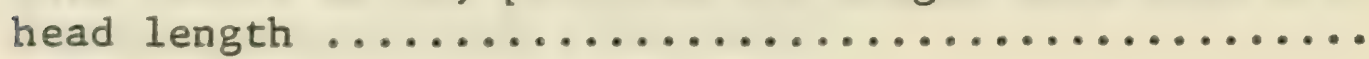

7 Pectoral fin length more than $11 / 5$ head length; ex- 
tending to anal fin or beyond; trailing edge of caudal fin edged with white.

\section{Albacore, Thunnus alalunga}

Pectoral fin length less than $11 / 5$ head length;

trailing edge of caudal fin not edged with white.....

8 Anal fin elongate, more than twice length of pelvic fins; body slender, its depth more than $33 / 4$ into its length; fins with large yellow areas; finlets lemonyellow.

Yellowfin tuna, Thunnus albacares

Anal fin not especially elongate, not more than twice length of pelvic fins; body stout, its depth less than $33 / 4$ into its length; no yellow patches on fins; finlets brownish yellow.

Bigeye tuna, Thunnus obesus

Key to families XIPHIIDAE and ISTIOPHORIDAE ${ }^{1}$

1 Pelvic fins absent; scales absent; sword stout and always flattened dorso-ventrally (Xiphiidae).

Swordfish, Xiphias gladius

Pelvic fins present; scales present, elongate; sword slender, cyclindrical or somewhat laterally com-

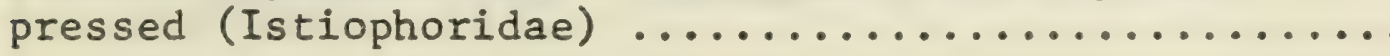

2 Anterior part of spinous dorsal fin rounded and higher than body depth at dorsal fin origin; flesh red; size usually smal1, less than 300 pounds. White marlin, Makaira albida $^{2}$

Anterior part of spinous dorsal fin pointed and low,

IAlthough the sailfish, Istiophorus albicans, has not been reported, it may be recognized by the large, spiny dorsal fin, in which the central spines are distinctly longer than the anterior ones.

${ }^{2}$ Also called Tetrapterus albidus Poey. 
its height less than body depth at dorsal fin origin; flesh pale; size larger, to 2000 pounds.

Blue marlin, Makaira nigricans

Key to suborder BLENNIOIDEA

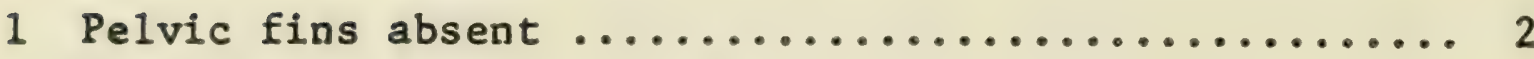

Pelvic fins present $\ldots \ldots \ldots \ldots \ldots \ldots \ldots \ldots \ldots \ldots \ldots \ldots$

2 Dorsal fin inserted behind head; dorsal, caudal and anal fins confluent or nearly so; mouth at oblique angle. Wrymouth, Cryptacanthodes maculatus

Dorsal fin inserted over opercles; caudal fin distinct and separate; mouth nearly horizontal; incisor teeth prominent.

Wolffishes, family Anarhichadidae (p.72)

3 Pelvic fins usually well developed but of few rays and located in advance of pectoral fins.

Pricklebacks, family Stichaeidae (p.73)

Pelvic fins much reduced in size, of one spine and one soft ray only, located under or behind pectoral fins.

Gunnels, family Pholidae (p.73)

\section{Key to family ANARHICHADIDAE}

1 Backward extension of vomerine teeth extending beyond palatine teeth, the vomerines noticeably larger than palatines; body distinctly barred especially anteriorly; (the more common species).

Atlantic wolffish, Anarhichas lupus

Backward extension of vomerine teeth not obviously extending beyond palatine teeth; body conspicuously spotted or blotchy but not distinctly barred ........ 2 
2 Body and head with distinct black spots; backward extension of palatine teeth beyond rear margin of vomerine teeth.

Spotted wolffish, Anarhichas minor

Body and head without distinct spotting, but sometimes with darker blotches; backward extension of vomerine and palatine teeth about equal.

Northern wolffish, Anarhichas denticulatus

Key to family PHOLIDAE

Dorsal spines 73-86 (usually 77-79); located along base of dorsal fin are 10-14 round, black spots; no light band running around head posterior to eyes.

Rock gunnel, Pholis gunnellus

Dorsal spines 84-91; along the back are 9-11 light blotches, margined with a black strip fore and aft;

a light band with black margins around head, posterior to eyes.

Banded gunnel, Pholis fasciata

\section{Key to family STICHAEIDAE}

1 Pelvic fins absent; lower jaw projecting; head broad, not compressed.

Wrymouth, Cryptacanthodes maculatus

Pelvic fins present although sometimes reduced... .2

2 Orbital tentacles or cirri present, 2 pairs, one pair longer.

Yarrell's blenny, Chirolophus ascani

Orbital tentacles or cirri absent $\ldots \ldots \ldots \ldots \ldots \ldots \ldots$

3 Dorsal fin spines less than 52; anal fin rays less than 37; body laterally compressed ................. 4

Dorsal fin spines more than 56; anal fin rays more than 
37 ; body less compressed

4 Four lateral lines; anal fin rays $29-32$; pectoral fin rays 17 or 18 .

Fourline snakeblenny, Eumesogrammus praecisus

One or 2 lateral lines; anal fin with $30-37$ rays;

pectoral fin rays 15 or $16 \ldots \ldots \ldots \ldots \ldots \ldots . .$.

5 Five distinct black blotches along dorsal fin; one incomplete lateral line, ending under anterior half of dorsal fin.

Arctic shanny, Stichaeus punctatus

One oblong black blotch on anterior portion of dorsal

fin (about 5 th-10th spines); one complete lateral line along mid flank, a 2nd incomplete lateral line above it, ending under anterior half of dorsal fin.

Radiated shanny, Ulvaria subbifurcata

6 Lower rays of pectoral fins elongated, free from membrane and almost finger-like.

Daubed shanny, Lumpenus maculatus

Lower rays of pectoral fins not elongate $. . . \ldots \ldots .$.

7 Dorsal fin rays $71-85$.

Snake blenny, Lumpenus lumpretaeformis

Dorsal fin rays less than $70 \ldots \ldots \ldots \ldots \ldots \ldots \ldots$

8 Dorsal fin rays 61-66; pectoral fin rays $15-17$; anal fin of uniform height.

Slender eelblenny, Lumpenus fabricii

Dorsal fin rays $58-63$; pectoral fin rays $13-15$; anal fin low in front, higher behind.

Stout eelblenny, Lumpenus medius 
Key to family ZOARCIDAE

1 Pelvic fins absent ........................ 2

Pelvic fins present ....................... 3

2 Teeth present on jaws.

Atlantic soft pout, Melanostigma atlanticum

Teeth absent.

Fish doctor, Gymnelis viridis

3 Posterior part of dorsal fin composed of short, stiff spines suggesting a distinct break between dorsal and caudal fins.

Ocean pout, Macrozoarces americanus

Dorsal fin continuous, without short, stiff spines on posterior part .......................... 4

4 Body elongate but stout; body depth (at anus) into body length 7 to 13 times (genus Lycodes) .......... 5

Body elongate and eel-1ike; body depth (at anus) into body length 16 to 30 times (genus Lycenchelys) ....... 11

5 Distance between snout and anus 35 to 44 percent of total length; peritoneum usually black; ventral lateral line present ............................. 6

Distance between snout and anus 45 to 52 percent of total length; peritoneum usually light; ventral lateral

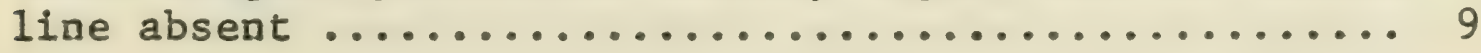

6 Pectoral fin rays $17-20 \ldots \ldots \ldots \ldots \ldots \ldots \ldots \ldots . \ldots . \ldots . \ldots$

Pectoral fin rays $21-24 \ldots \ldots \ldots \ldots \ldots \ldots \ldots \ldots . \ldots . \ldots$ 
7 Anal fin rays $79-85$; mid lateral line present.

Pale eelpout, Lycodes pallidus

Anal fin rays 96-102; mid lateral line absent.

Vahl's eelpout, Lycodes vahlii

8 Mid lateral line present.

Esmark's eelpout, Lycodes esmarki

Mid lateral line absent.

Atlantic eelpout, Lycodes atlanticus

9 Anal fin rays $77-82$; dorsal fin rays $97-104$.

Laval's eelpout, Lycodes lavalaei

Anal fin rays $64-77$; dorsal fin rays $82-95 \ldots \ldots \ldots 10$

10 Pectoral fin rays $16-18$ (rarely 19 ); mid lateral line present; scales usually absent.

Polar eelpout, Lycodes turneri

Pectoral fin rays 19-21; mid lateral line very distinct; scales weakly developed but present.

Arctic eelpout, Lycodes reticulatus

11 Dorsal and anal fins short, each of less than 100 rays, usually about 90 ( 92 and 88 respectively).

Wolf eelpout, Lycenchelys verrilli

Dorsal and anal fins long, each composed of more

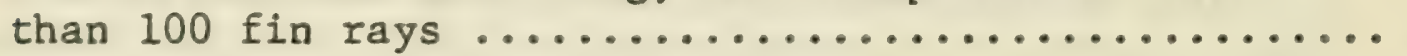

12 Dorsal fin rays 118; anal fin rays 110.

Common wolf eel, Lycenchelys paxillus

Dorsal fin rays 123; anal fin rays 117.

Sar's wolf eel, Lycenchelys sarsi 


\section{Key to family STROMATEIDAE}

1 Pelvic fins absent.

Butterfish, Poronotus triacanthus

Pelvic fins present $\ldots \ldots \ldots \ldots \ldots \ldots \ldots \ldots \ldots \ldots \ldots \ldots \ldots \ldots$

2 Spinous dorsal fin low, of 6-8 uniformly short spines; pelvic fins inserted behind pectoral fin base.

American barrelfish, Palinurichthys perciformes

Spinous dorsal fin triangular, of 10 or 11 spines; pelvic fins inserted under, or in advance of, pectoral fin base.

$$
\text { Man-o'-war fish, Nomeus gronowi }
$$

Key to species of suborder MUGILOIDEA

Anal fin long, of $22-25$ rays, with one weak spine commencing under first (spiny) dorsal fin; body slender and elongate.

Atlantic silverside, Menidia menidia

Anal fin short, of 7 or 8 rays, preceded by 3 strong spines; anal fin commencing under origin of 2 nd (soft) dorsal fin; body stout.

Striped mullet, Mugil cephalus

Key to family SCORPAENIDAE

Dorsal fin spines 12 .

Blackbelly rosefish, Helicolenus dactylopterus

Dorsal fin spines 14 or 15.

Redfish or ocean perch, Sebastes marinus

Key to family TRIGLIDAE

Pectoral fin extends back to 6 th ray of 2 nd dorsal fin; 
body and fins plain with dark mottling.

Northern searobin, Prionotus carolinus

Pectoral fin extends back to 9 th or 10 th ray of 2 nd dorsal fin; body with 2 dark, longitudinal stripes along each side.

Striped searobin, Prionotus evolans

\section{Key to family COTTIDAE}

1 Dorsal fins obvious and separated into 2 more or less distinct parts, but not a continuous fin .......... 2

Dorsal fins not separated but forming a single fin, this fin low and skin-covered, not conspicuous ...... 14

2 Head and chin with fleshy tabs; skin on body and head rugose or pebbly.

Sea raven, Hemitripterus americanus

Head and chin without fleshy tabs; skin mainly smooth

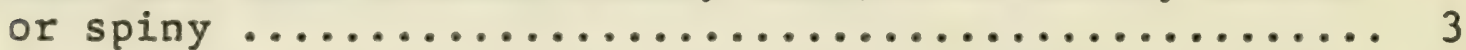

3 Palatine teeth present; upper preopercular spine either curved upward and simple, or deeply bifurcated ...... 4

Palatine teeth absent, upper preopercular spine straight and simple (sometimes inconspicuous), if curved upward then broad toward tip (Gymnocanthus)

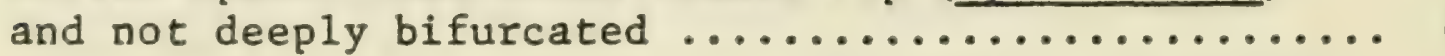

4 Upper preopercular spine pointed, not bifurcate, but strongly hooked upward; outer margin of dorsal fin often with dark pigment and both dorsal fins on males 
with distinct round or oblong spots.

Hookear sculpin, Artediellus uncinatus ${ }^{1}$

Upper preopercular spine obviously forked or bifurcate (sometimes 3-pronged); a row of spiny plates

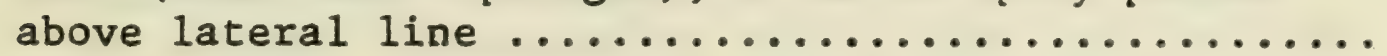

5 Lateral line plates with small spines below pores as well as above; lateral line often incomplete, terminating on the caudal peduncle.

Twohorn sculpin, Icelus bicornis

Lateral line plates without small spines below pores; lateral line usually complete.

Spatulate sculpin, Icelus spatula

6 Upper opercular spine broad or with 2 or 3 spinules or cusps toward tip; vomer without teeth.

Arctic staghorn sculpin, Gymnocanthus tricuspis

Upper opercular spine simple; vomer toothed...$\ldots .7$

7 Lateral line armed with rows of plates, each with backwardly directed spines; area below lateral line with folds arranged in oblique rows (Triglops) ......... 8

Lateral line not armed with rows of plates; area below lateral line not in folds; opercular and head spines usually well developed (Myoxocephalus) ............ 10

8 Pectoral fin rays 20-22; eye large, diameter of bony orbit greater than, or equal to, postorbital head length;

ISome authors distinguish two species as follows:

A. uncinatus - dorsal rays 12 or 13; anal rays 10-12; lateral line pores 24-28; dorsal fins of mature males with round, light spots.

A. atlanticus - dorsal rays $13-15$; anal rays $11-13$;

lateral line pores 18-25; dorsal fins of mature males with light bars or bands. 
body pigmentation restricted to 4 or 5 thin, oblique lines which in males tend to run together to form 2 lateral stripes; head usually dusky.

Nybelin's sculpin, Triglops nybelini

Pectoral fin rays 17-19; eye moderate, diameter of bony orbit not exceeding postorbital head length; pigment variable, usually 3 or 4 large dorsal blotches or a series of small irregular spots, or blotches,

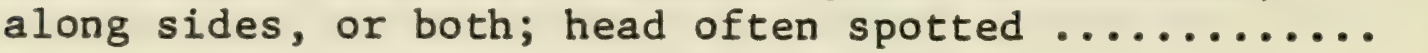

9 Caudal fin with 2 or 3 cross bars; a small black spot at the outer edge of membrane between first and 2 nd spines of first dorsal fin, spot most prominent in males; snout rounded.

Mailed sculpin, Triglops murrayi

Caudal fin without cross bars; no black spot at anterior tip of first dorsal fin; snout straight, somewhat like a duck's bill.

Ribbed sculpin, Triglops pingeli

10 Preopercular spines 4, 2 directed forward, the first concealed in skin, 2 directed rearward; at least 4 rough-topped spines atop head.

Fourhorn sculpin, Myoxocephalus quadricornis

Preopercular spines 3, one directed downward or forward, 2 directed rearward; top of head without

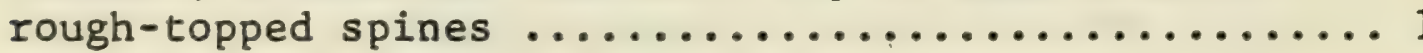

11 Upper preopercular spine long, about 4 times as 1 ong as spine below it; all head spines sharp.

Longhorn sculpin, Myoxocephalus octodecemspinosus

Upper preopercular spine not conspicuously long, at most twice as $10 n g$ as spine below it ............. 12

12 Origin of spinous dorsal fin in advance of posterior 
tip of operculum, tip usually under 3 rd or 4 th spine.

Grubby, Myoxocephalus aeneus

Origin of spinous dorsal fin not distinctly in advance of posterior tip of operculum ................. 13

13 Pectoral fin rays $14-16$; well developed fleshy tabs or cirri present over eyes.

Arctic sculpin, Myoxocephalus scorpioides

Pectoral fin rays 17 or 18; well developed spines over eyes, not cirri.

Shorthorn sculpin, Myoxocephalus scorpius

14 Skin slmost naked and smooth except for a few fine spines; eyes large, diameter greater than interorbital width; body colour grey-brown, without blotches.

Pallid sculpin, Cottunculus thompsoni

Skin rough; eyes small, the diameter less than interorbital width; head spotted; body usually with at least 3 broad bands of blotching.

Polar sculpin, Cottunculus microps

\section{Key to family AGONIDAE}

1 Two dorsal fins; 5 pairs of barbels about mouth.

Atlantic sea poacher, Agonus decagonus

A single dorsal fin; mouth with one pair of barbels,

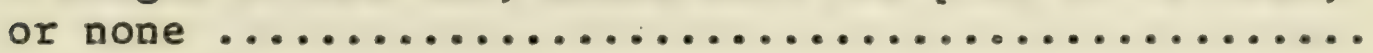

Barbels absent; body slender; dorsal plates in 46-49 rows.

Alligatorfish, Aspidophoroides monopterygius

One pair of barbels at corner of mouth; body short and stout; dorsal plates in 35-38 rows. Arctic alligatorfish, Aspidophoroides olriki 


\section{Key to family CYCLOPTERIDAE}

1 Two dorsal fins; skin usually with conical tubercles; caudal fin distinct from dorsal and anal fins (lump-

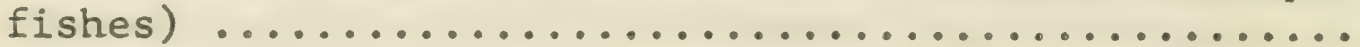

A single, long dorsal fin; skin naked; caudal fin usually confluent with dorsal and anal fins (seasnails)

2 Gill openings large, extending to below top of pectoral fin base.

Lumpfish, Cyclopterus lumpus

Gill openings small, not extending downward to base

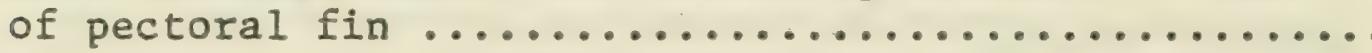

3 Chin and pectoral fin base without tubercles; no tubercles between dorsal fins.

Leatherfin lumpsucker, Eumicrotremus derjugini

Chin and pectoral fin base with tubercles, usually one or 2 spines between dorsal fins.

Atlantic spiny lumpsucker, Eumicrotremus spinosus

4 Adhesive (pelvic) disc absent.

Blacksnout seasnail, Paraliparis copei

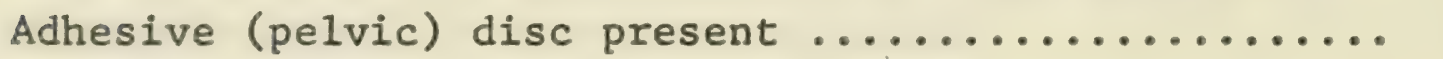

5 Nostrils with a single opening (Careproctus) ....... 6

Nostrils with a double opening ............... 7

6 Diameter of adhesive disc smaller than eye diameter. Longfin seasnail, Careproctus longipinnis

Diameter of adhesive disc larger than eye diameter. Sea tadpole, Careproctus reinhardi 
7 Peritoneum black; anal fin rays $37-41$.

Gelatinous seasnail, Liparis koefoedi

Peritoneum not black; anal fin rays 37 or fewer ..... 8

8 Anal fin rays 32 or more; dorsal fin rays 40 or more.. 9

Anal fin rays 30 or less; dorsal fin rays less than

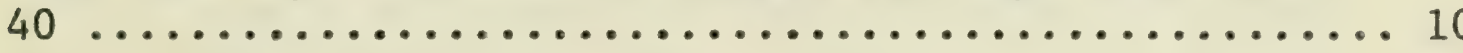

9 Pectoral fin rays $39-43$; gill slit extending downward in front of more than 10 pectoral fin rays.

Polka-dot seasnail, Liparis cyclostigma

Pectoral fin rays $35-38$; gill slit extending downward in front of 6 or fewer pectoral fin rays.

Greenland seasnail, Liparis tunicatus

10 Pectoral fin rays $26-28$; dorsal fin rays $32-35$;

pyloric caeca 19-37.

Atlantic seasnail, Liparis atlanticus

Pectoral fin rays 32 or 33 ; dorsal fin rays 34 or 35 ; pyloric caeca 10-13.

Striped seasnail, Liparis liparis

Key to order HETEROSOMATA - flatfishes

1 Eyes and pigment on right side $\ldots \ldots \ldots \ldots \ldots \ldots \ldots, 2$

Eyes and pigment on left side $\ldots \ldots \ldots \ldots \ldots \ldots \ldots, 8$

2 Mouth large, maxillary extending to below middle of eye or beyond; teeth well developed $\ldots \ldots \ldots \ldots \ldots \ldots .3$

Mouth smal1, maxillary extending at most to front of

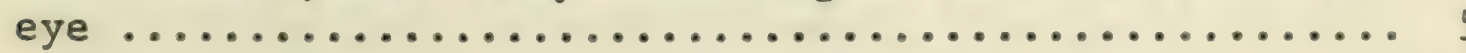

3 Caudal fin distinctly rounded; lateral line almost 
straight but curving slightly over pectoral fins; dorsal fin rays $75-96$; body colour reddish brown. American plaice, Hippoglossoides platessoides

Caudal fin slightly forked, not rounded, corners of caudal fin angular; dorsal fin rays 98-105; body colour gray brown or dark brown to olive ............

4 Lateral line arched above pectoral fin; dorsal fin rays 98-105; body colour dark and blotchy above, distinctly white below.

Atlantic halibut, Hippoglossus hippoglossus

Lateral line straight, even slightly decurved above pectoral fin; dorsal fin rays about 100; body colour grayish brown, creamy below but not white.

Greenland halibut, Reinhardtius hippoglossoides

5 Lateral line distinctly arched over pectoral fin; anal fin preceded by a short spine directed forward; body usually spotted.

\section{Yellowtail flounder, Limanda ferruginea}

Lateral line more or less straight $\ldots \ldots \ldots \ldots \ldots \ldots 6$

6 Lower blind side of head with circular depressions (sometimes called "pits"); right pectoral fin with conspicuous black pigment toward tip visible on fish 5 inches long and over; dorsal fin rays more than 100. Witch flounder, Glyptocephalus cynoglossus

No depressions on lower or blind side of head; pectoral fin without black pigment; dorsal fin rays

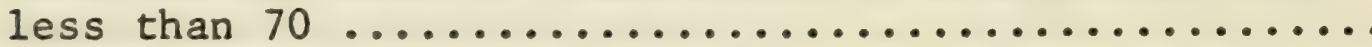

7 Region between eyes without scales (smooth to the touch); dorsal fin rays 55-58; body colour uniformly brown to almost black.

Smooth flounder, Liopsetta putnami

Region between eyes with scales (rough to the touch); 
dorsal fin rays $65-75$; body colour usually dark brown to black with spots or blotches.

Winter flounder, Pseudopleuronectes americanus

8 Body very deep (and thin), being almost round in outline; anterior 10 rays of dorsal fin free of membrane, lone, branched and fringe-like; left pelvic fin very broad at base, appearing almost as part of anal fin.

Windowpane, Scophthalmus aquosus

Body longer than deep; anterior dorsal fin rays not fringe-like; pelvic fins distinct and with narrow bases (Paralichthys) $\ldots \ldots \ldots \ldots \ldots \ldots \ldots \ldots \ldots \ldots$

9 Eyes small, interorbital distance about equal to diameter of pupil; number of gill rakers on outer arch 16-24; pigmented side with a number of black spots of different sizes.

Summer flounder, Paralichthys dentatus

Eyes large, interorbital distance much less than the diameter of pupil; number of gill rakers on outer arch 9-13; pigmented side with four prominent black spots only.

Fourspot flounder, Paralichthys oblongus

\section{Key to family ECHENEIDAE}

1 Disc laminae more than 20 (20-28); pectoral fins more or less pointed; body rather slender.

Sharksucker, Echeneis naucrates

Disc laminae less than 20 (14-18); pectoral fins rounded; body rather stout $\ldots \ldots \ldots \ldots \ldots \ldots \ldots \ldots \ldots$

2 Disc laminae 14-16; soft dorsal fin rays 29-32.

Spearfish remora, Remora brachyptera

Disc laminae 18; soft dorsal fin rays 22-25.

Remora, Remora remora 


\section{Key to family MONACANTHIDAE}

1 Anal fin rays usually fewer than 35; a prominent external spine extending from pelvic bone .......... 2

Anal fin rays usually more than 35; external pelvic

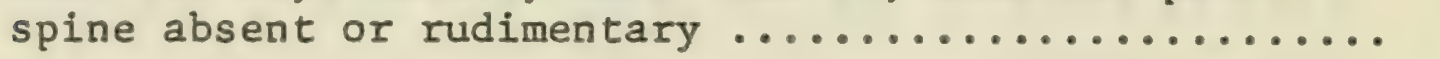

2 Two to 4 pairs of enlarged spines on each side of caudal peduncle; ventral flap relatively large; dorsal fin soft rays not elongated.

Fringed filefish, Monacanthus ciliatus

Caudal peduncle without paired spines; ventral flap sma11; 2nd dorsal fin ray elongated in mature males.

Planehead filefish, Monacanthus hispidus

3 Dorsal fin rays 32-39; anal fin rays 35-41; orange spots few or many.

Orange filefish, Alutera schoepfi

Dorsal fin rays $43-49$; anal fin rays $46-52$; no orange spots but dark green scrawled markings or spots.

Scrawled filefish, Alutera scripta

\section{Key to family BALISTIDAE}

Lateral line complete; body colour usually brown to gray; blue spots on dorsal, caudal and anal fins. Gray triggerfish, Balistes capriscus

Lateral line incomplete; 2 broad, blue lines on face and some radiating from eyes.

Queen triggerfish, Balistes vetula

Key to families TETRAODONTIDAE and DIODONTIDAE

1 Body covered with long, strong spines; teeth in each 
jaw fused together, beak-like (Diodontidae).

Striped burrfish, Chilomycterus schoepfi

Body naked or with only small, scattered prickles; teeth in each jaw fused but separated into 2 parts by median suture (Tetraodontidae) ...................

2 Soft dorsal fin rays 8 ; soft rays in anal fin 7 ; skin on anterior portions of head and body with fine prickles.

$$
\text { Northern puffer, Sphoeroides maculatus }
$$

Soft dorsal fin rays 15; soft rays in anal fin 14; strong, bony spines (with cross-shaped roots) on ventral surface.

Oceanic puffer, Lagocephalus lagocephalus

$$
\begin{array}{r}
\text { Key to species of order PEDICULATI - } \\
\text { anglerfishes, batfishes }
\end{array}
$$

1 Pelvic fins present $\ldots \ldots \ldots \ldots \ldots \ldots \ldots \ldots \ldots \ldots \ldots, 2$

Pelvic fins absent $\ldots \ldots \ldots \ldots \ldots \ldots \ldots \ldots \ldots \ldots, 4$

2 Head and body laterally compressed; colour pale yellow and marbled.

\section{Sargassumfish, Histrio histrio}

Head and body depressed or flattened dorso-ventrally.. 3

3 Illicium (first dorsal spine on head) long and slender; skin naked.

Monkfish, Lophius americanus

Illicium in form of a short rostral tentacle, bony and covered with small bony tubercles.

Atlantic batfish, Dibranchus atlanticus

4 Body with large bony plates, each with a median spine, 
scattered over body, no caruncles on back.

Atlantic footbalifish, Himantolophus groenlandicus

Body without large bony plates and with 2 or 3

caruncles on back

5 Back with 2 caruncles in front of soft dorsal fin on females, illicium long and slender; males without pigment on head or body.

Big deepsea angler, Ceratias holboelli

Back with 3 caruncles in front of soft dorsal fin on females, illicium short; males with pigment on gill cover, back and caudal peduncle.

Small deepsea angler, Cryptopsaras couesi 


\section{REFERENCES}

The following selected list of general and critical works contains much additional information that will assist in the identification of the marine fishes in the Canadian Atlantic region.

Berry, F. H. Young jack crevalles (Caranx species) off 1959 the southeastern Atlantic coast of the United States. U. S. Fish and Wildlife Serv., Fish Bul1., no. 152, Pp. 417-535.

Berry, F. H. and L. E. Vogele. Filefishes (Monacanthidae) 1961 of the western north Atlantic. U. S. Fish and Wildlife Serv., Fish Bul1., no. 181, pp. 61-109.

Bertelsen, E. The ceratioid fishes. Ontogeny, taxonomy, 1951 distribution and biology. Dana Rept., no. 39, pp. 1-276, $141 \mathrm{fig} ., 1 \mathrm{pl}$.

Bigelow, H. B. (editor-in-chief). Fishes of the western 1948-64 north Atlantic. Mem. Sears Foundation Marine Res. no. 1, pts. 1-4. (Orders Amphioxi to Giganturoidei).

Bigelow, H. B. and W. C. Schroeder. Fishes of the Gulf 1953 of Maine. U. S. Fish and Wildlife Serv., Fish Bul1., 53(74): 1-577.

1954

Deep water elasmobranchs and chimaeroids from the northwestern Atlantic slope. Bull. Mus. Comp. Zoo1., Harvard College, 112(2): 37-87.

Bolin, Rolf L. Iniomi, Myctophidae. From the "Michael 1959 Sars" North Atlantic deep-sea expedition, 1910. Rept. of the "Michael Sars" North Atlantic deep-sea Exped. 1910, vol. 4, II, no. 7, 45 pp.

Breder, C. M. Field book of marine fishes of the Atlantic 1948 coast. Putnam's Sons, New York and London, $332 \mathrm{pp}$.

Brown, J. L. A key to the species and subspecies of the 1957 cyprinodont genus Fundulus in the United States and Canada east of the continental divide. J. Washington Acad. Sci., 47(3): 69-77. 
Burke, V. Revision of the fishes of the family Liparidae. 1930 Bu11. U. S. Nat. Mus., 150, 204 pp.

Cohen, Daniel M. A revision of the fishes of the subfamily 1958 Argentinidae. Bull. Florida State Mus., Biol. Sci., 3(3): 93-172.

Collette, Bruce B. and Robert H. Gibbs, Jr. Preliminary 1963 field guide to the mackerel- and tuna-like fishes of the Indian Ocean (Scombridae). U. S. Nat. Mus. Smithsonian Inst., Washington, 48 pp.

de Sylva, D. P. and W. P. Davis. White marlin, Tetrap1957 turus albidus, in the Middle Atlantic Bight, with observations on the hydrography of the fishing grounds. Copeia, no.1: 81-99.

Ege, V. Paralepididae. I. (Paralepis and Lestidium). 1953 Dana Rept., (40): 1-184, 33 text figs.

Fraser-Brunner, A. The fishes of the family Scombridae. 1950 Ann. Mag. Nat. Hist., 12 ser., 3(26): 131-163.

Ginsburg, I. Fishes of the family Carangidae of the 1952 northern Gulf of Mexico and three related species. Pub1. Inst. of Marine Sci. 2(2): 43-117.

Grey, M. Fishes of the family Gempylidae, with records of 1953 Nesiarchus and Epinnula from the western Atlantic and descriptions of two new subspecies of Epinnula orientalis. Copeia, pp. 135-141.

Jordan, D. S. and B. W. Evermann. The fishes of North and 1896-1900 Middle America. Bul1. U. S. Nat. Mus., 47(1-4): $3313 \mathrm{pp} ., 392 \mathrm{pls}$.

Marsha11, N. B. Observations on the Heteromi, an order of 1962 teleost fishes. Bull. British Mus. (Nat. Hist.) Zool., 9(6): 251-270.

Mather, Frank J. III. A preliminary report on biometric 1959 studies of tunas (genus Thunnus) of the western north Atlantic. Woods Hole Oceanographic Institution, 9 pp., 9 figs. 
McAllister, D. E. List of the marine fishes of Canada. 1960 Nat. Mus. Canada, Bul1. no. 168, 76 pp.

1963 Systematic notes on the sculpin genera Artediellus, Icelus and Triglops on Arctic and Atlantic coasts of Canada. Nat. Mus. Canada, Bul1. no. 185, pp. 50-59.

Parr, A. E. The Macrouridae of the western North Atlantic 1946 and central American seas. Bull. Bingham Oceanog. Co11., 10(1): 1-99.

Perlmutter, Alfred. Guide to marine fishes. New York 1961 University Press, 431 pp.

Richards, S. W., A. Perlmutter and D. C. McAneny. A tax1963 onomic study of the genus Ammodytes from the east coast of North America (Teleostei: Ammodytes). Copeia, no.2: 358-377.

Schultz, L. P. Revision of the marine silver hatchet1961 fishes (family Sternoptychidae). Proc. U. S. Nat. Mus., 112(3449): 587-649.

Scott, W. B. and E. J. Crossman. Fishes occurring in the 1964 fresh waters of insular Newfoundland. Dept. of Fisheries, Queen's Printer, Ottawa, pp. 1-124.

Svetovidov, A. N. Gadiformes. Fauna of the U.S.S.R. 1948

Fishes. Acad. Sci. USSR. 9(4): 304 pp.

(English translation for Nat. Sci. Found., Washington, D. C., O.T.S. 63-11071).

Taning, A. V. Synopsis of the scopelids in the north 1928 Atlantic. Vidensk. Medd. dansk. naturh. Foren. 86: 49-69. Kjфbenhavn.

Templeman, W. Distribution of sharks in the Canadian 1963 Atlantic (with special reference to Newfoundland waters). Bull. Fish. Res. Bd. Canada, no. 140,77 pp.

Tibbo, S. N. and R. A. McKenzie. Tunas and bonitos. Fish. 1964 Res. Bd. Canada, Gen. Ser. Cir. 43: 1-4. 
Tucker, Denys $W$. Studies on the trichiuroid fishes. (3) 1956 A preliminary revision of the family Trichiuridae. Bull. British Mus. (Nat. Hist.), 4(3): $73-130$.

Vladykov, V. D. Preliminary list of marine fishes of 1961 Quebec. Le Nat. Canadien, Quebec, 88(3): 53-78.

Vladykov, V. D. and R. A. McKenzie. The marine fishes of 1935 Nova Scotia. Proc. Nova Scotian Inst. Sci., 19(1), 1934: 17-113.

Woolcott, W. S. Comparative osteology of serranid fishes 1957 of the genus Roccus (Mitchil1). Copeia, no.1: 1-10. 


\section{INDEX}

Underlined page numbers indicate location in the keys. Page numbers not underlined refer to position in the checklist.

Acipenser brevirostrum, $6, \underline{42}$

oxyrhynchus, $6, \underline{42}$

Acipenseridae, 6

key to, 42

Acipenseriformes, 6

Aethoprora, $\underline{52}$

metopoclampa, 8

Agonidae, 17

key to, 81

Agonus decagonus, $17, \underline{81}$

Albula vulpes, 6

Albulidae, $6, \underline{43}$

Alepisauridae, 9

key to, $\underline{55}$

Alepisaurus brevirostris, $9, \underline{55}$

ferox, 9, 55

Alepocephalidae, 7

key to, 44

Alepocephalus bairdii, 7, 44

Allotriognathi, 12

Alopias vulpinus, $4, \underline{21}$

Alopiidae, 4

Alosa aestivalis, $6, \underline{44}$

mediocris, 44

pseudoharengus, 6,44

sapidissima, 6,44

Alutera schoepfi, $18, \underline{86}$

scripta, $18, \underline{86}$

Ammodytes americanus, 14,69

dubius, 14, 69

Ammodytidae, 14

key to, 69

Anacanthini, $\overline{11}, 59$

Anarhichadidae, $15, \underline{72}$

key to, $\underline{72}$

Anarhichas denticulatus, 15, 73

lupus, $15, \underline{72}$

minor, $15, \frac{73}{7}$

Anchoa hepsetus, $\frac{7}{7}$ 
Anguilla rostrata, 9, $\underline{56}$

Anguillidae, 9

Anguilliformes, 9

Anoplogaster cornuta, 12, 65

Anoplogasteridae, 12

Anotopteridae, 9,31

Anotopterus pharao, 9

Antennariidae, 19

Antimora, 61 rostrata, 11

Apeltes quadracus, $11, \underline{58}$

Aphanopus carbo, 14, 69

Apodes, 9

key to, $\underline{55}$

Apogonidae, 13, 38

Apristurus profundorum, 4, 22

Archosargus probatocephalus, $14, \underline{68}$

Argentina silus, 7,48

striata, 7,48

Argentinidae, $7, \underline{45}$

key to, 47

Argyropelecus aculeatus, 8, 50

Artediellus atlanticus, $\underline{79}$

uncinatus, $16, \underline{79}$

Aspidophoroides monopterygius, 17, 81 olriki, 17, 81

Astronesthidae, 8,49

Atherinidae, 16

Auxis thazard, 14, 70

Balistes capriscus, $18, \underline{86}$

vetula, $18, \underline{86}$

Balistidae, 18

key to, 86

Bathylagidae, 7,45

Bathylagus euryops, 7

Bathypteroidae, 9,31

Bathypterois dubius, 9

Belonidae, 33

Beloniformes, 10

Benthodesmus simonyi, 14, 69

Benthosema, 53

glaciale, 8

Berycidae, 12

Beryciformes, 12 
Berycomorphi, 12

$$
\text { key to, } 64
$$

Beryx decadactylus, 12, 65 splendens, 12,65

Blennioidea, key to, $\frac{72}{28}$

Bony fishes, key to, $\underline{28}$

Boreogadus, 60 saida, $\frac{60}{11}$

Borostomias antarcticus, 8

Bothidae, 17

Brama rayi, 13, 68

Bramidae, 13

key to, 68

Branchiostegidae, 13, 37

Brevoortia tyrannus, 6,44

Brosme, 59

brosme, 11

Carangidae, 13

key to, 66

Caranx crysos, 13,67

hippos, 13, 67

Carcharhinidae, 4

Carcharhinus longimanus, 4,24 obscurus, $4, \underline{24}$

Carcharias taurus, $4, \underline{22}$

Carchariidae, 4

Carcharodon carcharias, 4, 23

Careproctus longipinnis, 17,82 reinhardi, $17, \underline{82}$

Centrobranchus, $9,5 \overline{3}$

Centroscyllium fabricii, 5, 24

Centroscymnus coelolepis, $5, \underline{24}$

Ceratias holboel1i, 19, $\underline{88}$

Ceratiidae, 19

Ceratoscopelus, 54 madeirensis, 8

Cetorhinidae, 4

Cetorhinus maximus, 4, 22

Chaetodon ocellatus, 14

Chaetodontidae, $14, \underline{39}$

Chauliodontidae, $8, \underline{48}$

Chauliodus sloani, 8

Chiasmodon niger, 14

Chiasmodontidae, 14, 37 
Chilomycterus schoepfi, 18, 87

Chimaeridae, 6

$$
\text { key to, } 28
$$

Chimaeriformes, 6,20

Chirolophus ascani, 15, 73

Chondrostei, 6

Clupea harengus, $6, \underline{43}$

Clupeidae, 6

key to, $\frac{43}{6}$

Clupeiformes,

key to, 42

Coelorhynchus carminatus, 12,64

Conger oceanicus, $10, \underline{56}$

Congridae, 10

Coregonus clupeaformis, 7, 47

$$
\text { sp., } 7,47
$$

Coryphaena hippurus, 13

Coryphaenidae, 13, 35

Coryphaenoides rupestris, 12,64

Cottidae, 16

$$
\text { key to, } \frac{78}{16}
$$

Cottunculus microps, $16, \underline{81}$

$$
\text { thompsoni, } 16,81
$$

Cryptacanthodes maculatus, 15, 72, 73

Cryptopsaras couesi, $19, \underline{88}$

Cyclopteridae, 17

$$
\text { key to, } 82
$$

Cyclopterus lumpus, 17, 82

Cyclothone braueri, 7, $\underline{50}$ microdon, $7, \underline{50}$

Cynoscion regalis, 14,68

Cyprinodontidae, 11 key to, 57

Cyprinodontiformes, 11

Cypselurus furcatus, $10, \underline{57}$

heterurus, $10, \underline{57}$

Dactylopteridae, 17, 36

Dactylopterus volitans, 17

Dalatiidae, 5

Dasyatidae, 5

Dasyatis centroura, 5, 25

Decapterus macarellus, $13, \underline{67}$ 
Diaphus, $9, \underline{52}$

Dibranchus atlanticus, 19, 87

Diodontidae, 18 key to, 86

Diogenichthys, 9,53

Diretmidae, 12

Diretmus argenteus, 12, 65

Discocephali, 18

Echeneidae, 18

key to, 85

Echeneiformes, 18

Echeneis naucrates, 18, 85

Elopidae, 6, 42

Enchelyopus, $\underline{61}$ cimbrius, 11

Engraulidae, 7, 43

Epinephelus morio, 13, 66

Etmopterus princeps, 5, 25

Etrumeus sadina, 6,43

Eumesogrammus praecisus, 15, 74

Eumicrotremus derjugini, $17, \overline{82}$ spinosus, 17,82

Eurypharyngidae, $9, \frac{41}{1}$

Eurypharynx pelecanoides, 9

Euthynnus pelamis, 14, 70

Exocoetidae, 10

key to, 57

Fistularia tabacaria, 11

Fistulariidae, $11, \underline{33}$

Fundulus diaphanus, $11, \underline{58}$

heteroclitus, 11,58

Gadidae, 11

key to, 59

Gadifornes, 11

Gadus, 60

key to, 61

morhua, 11,62

ogac, 11,62

Gaidropsarus, $6 \overline{1}$

key to, $\underline{62}$ 


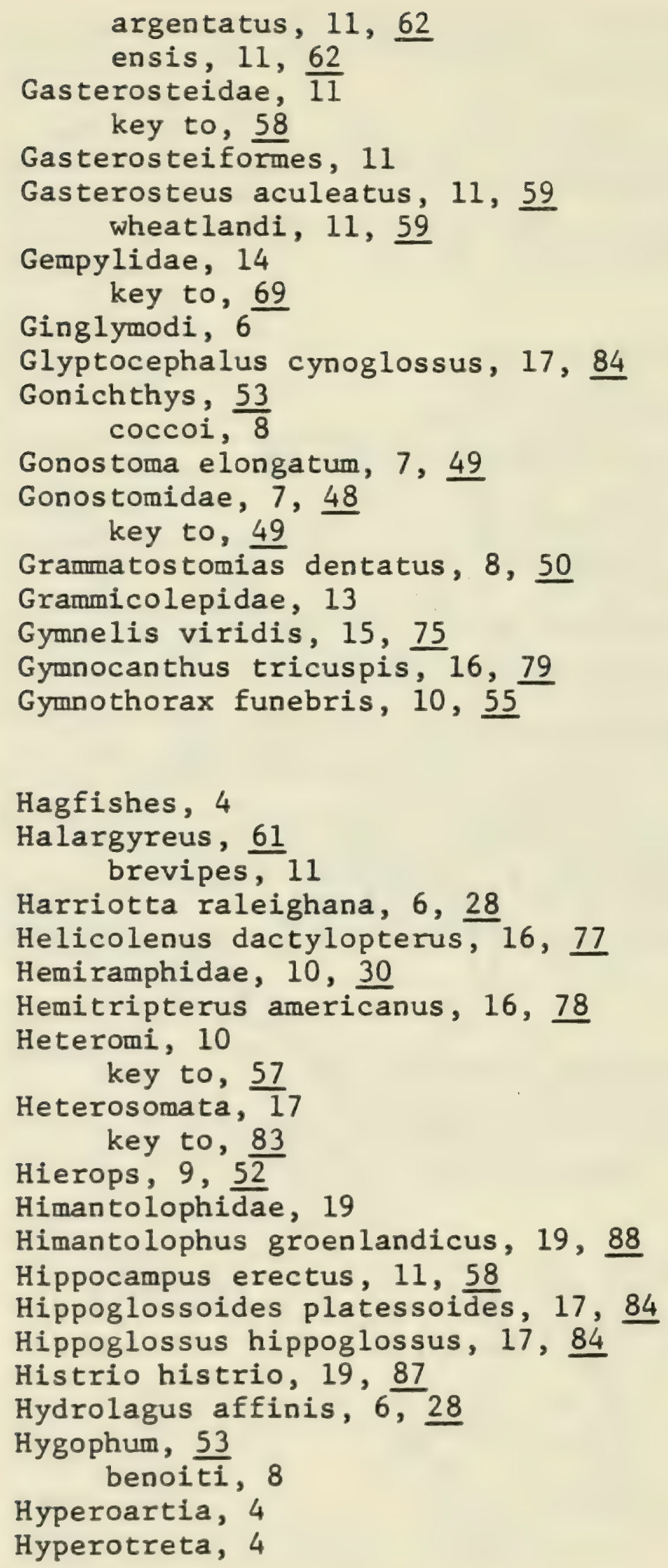


Hyporhamphus sp., 10

Hypotremata, 5, 20

key to, $\underline{25}$

Icelus bicornis, 16,79

spatula, 16,79

Idiacanthidae, $8, \overline{49}$

Idiacanthus fasciola, 8

Iniomi, 8

Isospondy $1 i, 6$

Istiophoridae, 15

key to, 71

Istiophorus albicans, 71

Isurus oxyrinchus, $4, \underline{\underline{23}}$

Labridae, 14

key to, 68

Lactophrys trigonus, 18

Lagocephalus lagocephalus, 18, 87

Lamna nasus, $4, \underline{23}$

Lamnidae, 4

Lampadena, 54 speculigera, 8

Lampanyctus, $\underline{54}$

Lampreys, 4 crocodilus, 9

Lamprididae, 12,35

Lampridiformes, 12

Lampris regius, 12

Lepidocybium flavobrunneum, 14, 69

Lepidophanes, 9,54

Lepisosteidae, $6, \underline{29}$

Lepisosteus osseus, 6

Lestidium, 54

Limanda ferruginea, 18,84

Liopsetta putnami, 18,84

Liparis atlanticus, $17, \underline{83}$

cyclostigma, 17,83

koefoedi, $17, \frac{83}{3}$

liparis, $17,8 \overline{3}$

tunicatus, 17,83

Lipogenyidae, 10

Lipogenys gillii, 10, $\underline{57}$

Lobianchia, 9, $\underline{52}$ 
Lophiidae, 19

Lophifformes, 19

Lophius americanus, 19, 87

Lopholatilus chamaeleonticeps, 13

Loweina, 9, $\underline{53}$

Lumpenus fabricii, 15, 74

lumpretaeformis, $15, \underline{74}$

maculatus, $15, \underline{74}$

medius, 15,74

Lycenchelys paxilius, $15, \underline{76}$

sarsi, 15, 76

verrilli, 15,76

Lycodes atlanticus, 15,76

esmarki, 15,76

lavalaei, $15, \frac{76}{76}$

pallidus, $15, \overline{76}$

reticulatus, 15,76

turneri, 15,76

Lyomeri, 9

vahlii, $15, \underline{76}$

Macdonaldia rostrata, 10,57

Macrouridae, 12

key to, 63

Macrourus berglax, 12, 64

Macrozoarces americanus, 15, 75

Major categories, key to, 20

Makaira albida, 15, $\frac{71}{72}$

nigricans, $15, \frac{71}{72}$

Malacocephalus occidentalis, 12, 64

Malacosteidae, 8,48

Malacosteus niger, 8

Mallotus villosus, 7, 47

Manta birostris, 5, 25

Marsipobranchii, $4, \underline{20}$

key to, 21

Maurolicus muelleri, 8, 49

Megalops atlanticus, 6

Melamphaidae, 12

Melanogrammus, $\underline{60}$

aeglefinus, 11

Melanostigma atlanticum, 16, 75

Melanostomias spilorhynchus, $8, \underline{51}$

Melanostomiatidae, $8, \underline{49}$

key to, $\underline{50}$ 
Menidia menidia, 16, 77

Merluccius, 61

key to, $\frac{62}{1}$

albidus, 11,62

bilinearis, $1 \overline{2}, \underline{62}$

Microcyprini, 11

Microgadus, 60 tomcod, 12

Micromesisteus, $\frac{60}{12}$

poutassou, $\overline{12}$

Mobulidae, 5

Mola mola, 18

Molidae, 18,41

Molva, 61

key to, 62

byrkelange, 12, 62

molva, $12, \underline{63}$

Monacanthidae, 18

key to, 86

Monacanthus ciliatus, $18, \underline{86}$

hispidus, $18, \underline{86}$

Moridae, 11

key to, 59

Mugil cephalus, 16, 77

Mugilidae, 16

Mugiloidea, 16

key to, 77

Mullidae, $14, \frac{37}{37}$

Mullus auratus, 14

Muraenidae, 10

Mustelus canis, 4, 22

Myctophidae, 8

key to, 51

Myctophiformes, 8

Myctophinae, 51

Myctophum, 53

affine, 9

punctatum, 9

Myoxocephalus aeneus, 16, 81

octodecemspinosus, 16,80

quadricornis, 16,80

scorpioides, 17,81

scorpius, 16,81

Myxine glutinosa, 4, 21

Myxinidae, 4

Myxiniformes, 4 
Nansenia groenlandica, 7, 47

Naucrates ductor, 13, 67

Nemichthyidae, 10

Nemichthys scolopaceus, 10, 57

Neoscopelinae, $\underline{51}$

Neoscopelus, 9

Nessorhamphidae, 10

Nessorhampus ingolfianus, 10,56

Nezumia bairdi, 12,64

Nomeus gronowi, $16, \overline{77}$

Notacanthidae, 10

Notacanthiformes, 10

Notacanthus nasus, 10,57

Notolychnus, 9,52

Notoscopelus, 54

krøyeri, 9

Ogcocephalidae, 19

Omochelys cruentifer, 10, 57

Oncorhynchus gorbuscha, $7, \underline{46}$

Ophichthidae, 10

Osmeridae, 7, 45

key to, $4 \overline{7}$

Osmerus mordax, 7,47

Osteichthys, 6,20

Ostraciontidae, $\overline{18}, 41$

Palinurichthys perciformis, 16, 77

Paralepididae, 9 key to, 54

Paralepis brevis brevis, 9, $\frac{55}{55}$ coregonoides borealis, $\underline{55}$

rissoi krфyeri, 9, 55

Paralichthys dentatus, 17,85 oblongus, $17, \frac{85}{17}$

Paraliparis copei, $\overline{17}, \underline{82}$

Pediculati, 19

key to, $\frac{87}{13}$

Perciformes, $\overline{13}$

Percomorphi, 13

Petromyzon marinus, 4, 21

Petromyzontidae, 4

Petromyzontiformes, 4

Pholidae, 15, $\underline{72}$ 


$$
\text { key to, } 73
$$

Pholis fasciata, 15,73 gunnellus, $15, \underline{73}$

Pisces, 6, 20

Plectognathi, 18

Pleuronectidae, 17

Pleuronectiformes, 17

Pleurotremata, 4, 20

key to, 21

Pogonias cromis, 14,68

Pollachius, 60

$$
\text { virens, } \frac{12}{12}
$$

Polyipnus asteroides, $8, \underline{50}$

Polymixia nobilis, 12, 64

Polymixiidae, 12

Polyprion americanus, $13, \underline{66}$

Pomatomidae, 13,38

Pomatomus saltatrix, 13

Poronotus triacanthus, 16, 77

Prionace glauca, 5, 23

Prionotus carolinus, $16, \underline{78}$

evolans, $16, \underline{78}$

Pseudopleuronectes americanus, $18, \underline{85}$

Pungitius pungitius, $11, \underline{58}$

Raja bathyphila, 5, 26

$$
\begin{aligned}
& \text { erinacea, 5, 27, } 28 \\
& \text { fyllae, 5, } \frac{28}{26} \\
& \text { jenseni, 5, } \frac{26}{6} \\
& \text { laevis, 5, } \frac{26}{26}, \underline{27} \\
& \text { lintea, 5, } \\
& \text { mollis, 5, } \frac{27}{28} \\
& \text { ocellata, 5, } \frac{28}{6} \\
& \text { radiata, 5, } \frac{26}{27} \\
& \text { senta, 5, } 26 \\
& \text { spinicauda, } 5, \underline{26}
\end{aligned}
$$

Rajidae, 5

Rajiformes, 5

Rays, 5

key to, 25

Reinhardtius hippoglossoides, 18,84

Remora brachyptera, 18, 85

remora, 18,85

Rhectogramma sherborni, 13

Rhinochimaera atlantica, 6, 28 
Rhizoprionodon terraenovae, 5, 23

Roccus americanus, $13, \underline{66}$

Ruvettes pretiosus, $\frac{66}{14}, \underline{69}$

Saccopharyngiformes, 9

Salmo gairdneri, 7, 46

salar, 7,46

trutta, $7, \frac{46}{45}$

Salmonidae, $7, \underline{45}$

key to, 45

Salmonoidea, $\frac{4}{7}$

key to, 44

Salvelinus alpinus, 7,47

fontinalis, 7,47

Sarda sarda, 14, 70

Sciaenidae, 14

key to, 68

Scleroparei, $\overline{16}$

Scomber colias, 14, 70

scombrus, $14, \underline{70}$

Scomberesocidae, 10,33

Scomberesox saurus, 10

Scombridae, 14

key to, 70

Scopeliformes, 8

Scopelogadus beanii, 12, 65

Scopelopsis, 9, 53

Scophthalmus aquosus, 17, 85

Scorpaenidae, 16

key to, $\underline{77}$

Scyliorhinidae, 4

Sebastes marinus, 16, 77

Selachii, 4, 20

Selar crumenophthalmus, 13, 67

Selene vomer, 13,68

Semiontiformes, 6

Seriola zonata, 13, 67

Serranidae, 13

key to, 66

Serrivomer beani, 10, $\underline{57}$

Sharks, 4

$$
\text { key to, } 21
$$

Simenchelyidae, 9

Simenchelys parasiticus, 9, $\underline{56}$ 
Solenichthys, 11

Somniosus microcephalus, 5, 24

Sparidae, 14

$$
\text { key to, } 68
$$

Sphoeroides maculatus, 18,87

Sphyrna zygaena, 5, 21

Sphyrnidae, 5

Squalidae, 5

Squaliformes, 4

Squalus acanthias, 5, 24

Stenotomus chrysops, $1 \overline{4}, \underline{68}$

Sternoptychidae, 8, 48

key to, 50

Sternoptyx diaphana, 8, $\underline{50}$

Stichaeidae, $15, \underline{72}$

key to, $\underline{73}$

Stichaeus punctatus, $15, \underline{74}$

Stomias boa ferox, 8

Stomiatidae, $8, \underline{49}$

Stomiatoidea, 7

key to, 48

Stromateidae, 16

Sudidae, 9

$$
\text { key to, } 77
$$

Symbolophorus, $\underline{53}$

veranyi, 9

Synaphobranchidae, 10

Synaphobranchus kaupi, 10, $\underline{56}$

Synentognathi, 10

Syngnathidae, 11

key to, $\underline{58}$

Syngnathus fuscus, $11, \underline{58}$

Taaningichthys, 9,54

Taractes longipinnis, 14, 68

Tautoga onitis, 14, 69

Tautogolabrus adspersus, 14, 69

Tetraodontidae, 18

key to, 86

Tetraodontiformes, 18

Tetrapterus albidus, 71

Thoracostei, 11

Thunnus albacares, 14, 71

alalunga, 14,71

obesus, 14,71 


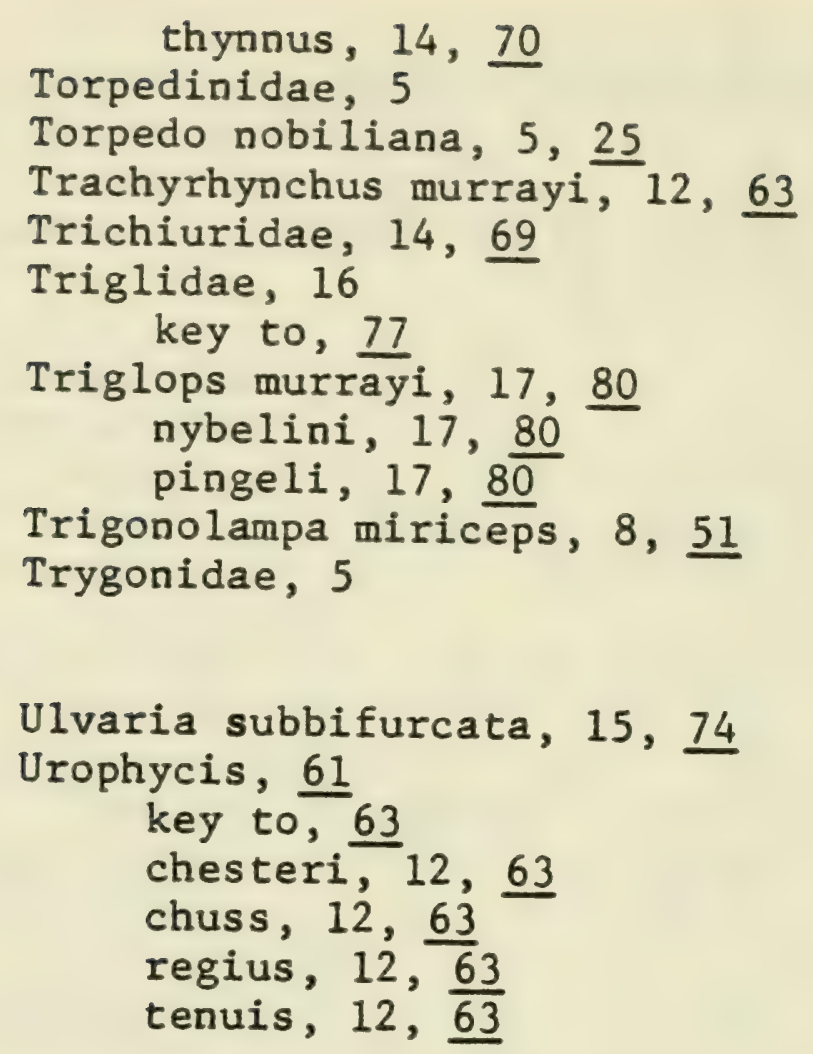

Vomer setapinnis, $13, \underline{68}$

Xenodermichthys socialis, 7,44

Xenolepidichthys americanus, $\overline{13}, 65$ Xiphias gladius, 15, 71

Xiphiidae, 15

key to, $\underline{71}$

\section{Zeidae, 13}

Zeiformes, 13

Zenopsis ocellata, 13, $\underline{65}$

Zeomorphi, 13

key to, 65

Zoarcidae, 15

key to, $\underline{75}$ 




512. 


LIBRARY

ROYAL ONTARIO MUSEUM 
157) Whom 36-

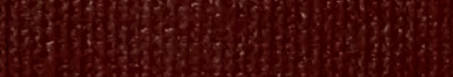
1937) 